Article

\title{
In Vivo Healthy Benefits of Galacto-Oligosaccharides from Lupinus albus (LA-GOS) in Butyrate Production through Intestinal Microbiota
}

\author{
Lucila A. Godínez-Méndez ${ }^{1}\left(\mathbb{0}\right.$, Carmen $^{\text {M. Gurrola-Díaz }}{ }^{2}{ }^{\circledR}$, José Sergio Zepeda-Nuño ${ }^{3}{ }^{\circledR}$, \\ Natali Vega-Magaña ${ }^{3}{ }^{(\mathbb{0}}$, Rocio Ivette Lopez-Roa ${ }^{4}{ }^{\mathbb{D}}$, Liliana Íñiguez-Gutiérrez ${ }^{1}$, Pedro M. García-López ${ }^{5}$, \\ Mary Fafutis-Morris ${ }^{1}$ a and Vidal Delgado-Rizo ${ }^{1, *}$
}

1 Departamento de Fisiología, CIINDE, Centro Universitario de Ciencias de la Salud, Universidad de Guadalajara, Guadalajara 44340, Jalisco, Mexico; ariadnegodinez@gmail.com (L.A.G.-M.); lilianainiguez11@gmail.com (L.Í.-G.); mfafutis@gmail.com (M.F.-M.)

2 Departamento de Biología Molecular y Genómica, Centro Universitario de Ciencias de la Salud, Universidad de Guadalajara, Guadalajara 44340, Jalisco, Mexico; carmenhpv@yahoo.de

3 Departamento de Microbiología y Patología, Centro Universitario de Ciencias de la Salud, Universidad de Guadalajara, Guadalajara 44340, Jalisco, Mexico; jsergio.zepeda@academicos.udg.mx (J.S.Z.-N.); alejandra.vega@academicos.udg.mx (N.V.-M.)

check for updates

Citation: Godínez-Méndez, L.A.; Gurrola-Díaz, C.M.; Zepeda-Nuño, J.S.; Vega-Magaña, N.; Lopez-Roa, R.I.; Íñiguez-Gutiérrez, L.; García-López, P.M.; Fafutis-Morris, M.; Delgado-Rizo, V. In Vivo Healthy Benefits of Galacto-Oligosaccharides from Lupinus albus (LA-GOS) in Butyrate Production through Intestinal Microbiota. Biomolecules 2021, 11, 1658. https://doi.org/ 10.3390/biom11111658

Academic Editor: Nicolas Cenac

Received: 21 September 2021 Accepted: 2 November 2021 Published: 9 November 2021

Publisher's Note: MDPI stays neutral with regard to jurisdictional claims in published maps and institutional affiliations.

Copyright: () 2021 by the authors. Licensee MDPI, Basel, Switzerland. This article is an open access article distributed under the terms and conditions of the Creative Commons Attribution (CC BY) license (https:// creativecommons.org/licenses/by/ $4.0 /)$.
4 Departamento de Farmacobiología, Centro Universitaro de Ciencias Exactas e Ingenierias, Universidad de Guadalajara, Guadalajara 44430, Jalisco, Mexico; rocio.lopez@academicos.udg.mx

5 Departamento de Botánica y Zoología, Centro Universitario de Ciencias Biologíco y Agropecuarias, Universidad de Guadalajara, Guadalajara 45200, Jalisco, Mexico; macedonio54@gmail.com

* Correspondence: vidalrizo@gmail.com; Tel.: +52-33-105-85-200 (ext. 33748)

\begin{abstract}
Animal digestive systems host microorganism ecosystems, including integrated bacteria, viruses, fungi, and others, that produce a variety of compounds from different substrates with healthy properties. Among these substrates, $\alpha$-galacto-oligosaccharides (GOS) are considered prebiotics that promote the grow of gut microbiota with a metabolic output of Short Chain Fatty Acids (SCFAs). In this regard, we evaluated Lupinus albus GOS (LA-GOS) as a natural prebiotic using different animal models. Therefore, the aim of this work was to evaluate the effect of LA-GOS on the gut microbiota, SCFA production, and intestinal health in healthy and induced dysbiosis conditions (an ulcerative colitis (UC) model). Twenty C57BL/6 mice were randomly allocated in four groups ( $n=5$ /group): untreated and treated non-induced animals, and two groups induced with $2 \%$ dextran sulfate sodium to UC with and without LA-GOS administration $(2.5 \mathrm{~g} / \mathrm{kg} \mathrm{bw})$. We found that the UC treated group showed a higher goblet cell number, lower disease activity index, and reduced histopathological damage in comparison to the UC untreated group. In addition, the abundance of positive bacteria to butyryl-CoA transferase in gut microbiota was significantly increased by LA-GOS treatment, in healthy conditions. We measured the SCFA production with significant differences in the butyrate concentration between treated and untreated healthy groups. Finally, the $\mathrm{pH}$ level in cecum feces was reduced after LA-GOS treatment. Overall, we point out the in vivo health benefits of LA-GOS administration on the preservation of the intestinal ecosystem and the promotion of SCFA production.
\end{abstract}

Keywords: Lupinus albus; short chain fatty acids; ulcerative colitis; intestinal microbiota; dysbiosis; goblet cells; butyryl-CoA transferase gene

\section{Introduction}

The gut microbiome is a complex natural ecosystem that is composed of fungi, viruses, parasites, archaea, and bacteria [1]. Bacteria are around $90 \%$ of the total gut microbiota [2,3]. Five phyla primarily compose the taxonomy of the intestinal bacteria. Firmicutes and Bacteroidetes are the major phyla including more than $90 \%$ of all microbiota [4]. Proteobacteria, 
Actinobacteria, and Verrucomicrobia phyla constitute the remaining percentage [5]. In the host, the intestinal health depends on the gut microbiota balance, Short Chain Fatty Acid (SCFA) production, tight junction protein regulation, and $\mathrm{pH}$ levels, among others [6-8].

Intestinal homeostasis is achieved through diverse functions of gut microbiota like nutrients and energy supply to the intestine, inhibition of pathogens colonization, balance pro-inflammatory and anti-inflammatory mediators, and production of metabolites that promote a healthy environment $[9,10]$. On the other hand, intestinal health may be disrupted by a loss of proportion in the microbiota phyla [11]. This effect is known as dysbiosis and is generally associated with inflammation and damage to the intestine [12]. Dysbiosis is characterized by a loss of diversity, structure, or function of the gut microbiota [13].

Several diseases are related to a dysbiotic state, including inflammatory bowel disease (IBD), obesity, diabetes, autoimmunity, allergy, and cancer [14]. In particular, a modification in the phyla distribution is clearly associated with the pathogenesis of Ulcerative Colitis (UC), a disease that is included in the IBD [15]. Indeed, the functional diversity and stability of intestinal bacteria are impaired in the intestinal microbial population from UC patients [16]. Previously, it was reported that UC is characterized by a reduction of Firmicutes and an increase of Bacteroidetes and facultative anaerobes [17]. In addition to the gut microbiota, other factors have been implicated in the development of UC, including a dysregulated immune response, genetic susceptibility, and environmental factors [15].

The UC is characterized by mucosal inflammation that initiates in the rectum and extends proximally in the colon [18]. Various experimental mice models have been development to investigate the pathogenesis of UC [19]. The most commonly induced experimental colitis is by dextran sulfate sodium (DSS). This model is simple and affords a high degree of uniformity and reproducibility of most lesions in the distal colon [20].

The diagnosis of UC in humans and in experimental models considers clinical symptoms. The pharmacological management of UC includes amino-salicylates (5-ASA), corticosteroids, and thiopurines [21]. However, corticosteroids can produce severe secondary effects, including osteoporosis, depression, type 2 diabetes mellitus, and cataracts [22]. Therefore, therapeutic alternatives are necessary to complement the pharmacological treatment and reverse the dysbiosis process and foment a healthy ecosystem in the intestine.

In recent years, prebiotics have been used as nutritional complements to modulate the gut microbiota ecosystem [23]. Prebiotics are classically defined as "a substrate that is selectively utilized by host microorganism conferring a health benefit" [24]. Taking into consideration the concept of a prebiotic described by the Association for Probiotics and Prebiotics (ISAPP), new compounds, such as nanoparticles, can participate as prebiotic sources [25]. The most evaluated prebiotics are fructo-oligosaccharides (FOS), galactooligosaccharides (GOS), and cyclodextrins (CDs) [26].

Prebiotics produce several beneficial effects exerted by the gut microbiota on the host. Particularly, it has been observed that populations from Bifidobacterium, Lactobacillus, and lactic acid bacteria increase after prebiotics administration [27,28]. Furthermore, these bacteria utilized as principal source hexose and pentoses come from prebiotics and transform it into pyruvate through the Embden-Meyerhof-Parnassian or pentose-phosphate pathways.

The end products of fermentation include the SCFAs and formic and lactic acids [29]. The SCFA production is related to intestinal health. In fact, SCFAs participate in many important functions in the intestine. Acetate, propionate, and butyrate are the three major SCFAs produced during bacterial fermentation. These acids promote the energy supply for enterocytes, the regulation of the expression and distribution of tight junction proteins as well as the maintenance of the goblet cell population and its subsequent mucus production, and the restoration of the integrity of the intestinal barrier [30].

Patients with IBD show reduced levels of total SCFAs in feces [31]. In the UC experimental model, the butyric acid was significantly decreased [32]. Lower butyrate concentration is associated with the permeability of epithelium, loss of the tight junction proteins, and inflammation mediated via NF- $\mathrm{kB}$, among others $[33,34]$. New approaches 
encourage the use of prebiotics to promote butyrate production to mitigate the damage of UC [34].

Prebiotics are contained in plants and are now used to improve human nutrition. Some edible plants rich in oligosaccharides include lupin, chicory, asparagus, and garlic, among others [26]. Lupin is an important legume that has been consumed for centuries by inhabitants of the Mediterranean and Andean regions [35]. Lupin's crop protein is important both as food for animals and in human nutrition and as a nutraceutical source [36]. There exist many scientific reports about lupin proteins indicating antihypertensive, hypoglycemic, and anti-hypercholesteremic effects [37,38]. In addition, lupins, like other legumes, contain soluble carbohydrates-for instance sucrose, raffinose, stachyose, and verbascose [39].

These oligosaccharides belonging to the GOS family and are formed by 1-6 galactosides linked to C6 of the glucose moiety of sucrose [39]. GOS from Lupinus albus (LA-GOS) possess prebiotic proprieties that promote the growth of gut bifidobacterial and Lactobacillus present in the large intestine of mammals with the production of SCFAs [40]. These compounds propitiate an environment that allows the grow of benefit microbiota that avoid infection by pathogenic bacteria [41]. The effects of LA-GOS in the gut microbiota have only been evaluated in an in vitro ecosystem with Lupinus albus seeds. In this study, L. albus increased the SCFA production, in the same manner as FOS and analogous to LA-GOS [42].

Prebiotic Sources (GOS, FOS, xylitol, and arabinoxylans) have been shown to have a positive effect in the modulation of intestinal microbiota, such as in Lupinus species [43-45]. Nevertheless, GOS from Lupinus albus have not been evaluated in the maintenance of gut microbiota balance and its intestinal effects. Considering the relevant role of prebiotics in preserving natural ecosystems, like the gut microbiota and its related effects on SCFA production, we aimed to evaluate the effect of GOS from L. albus under healthy and dysbiotic conditions, including experimental UC.

\section{Materials and Methods}

\subsection{Extraction of GOS from Lupinus albus}

Lupinus albus flour was obtained from dehulled seeds, ground to $2 \mathrm{~mm}$ particle size, and defatted with hexane. The $\alpha$-galactooligosaccharides extraction was carried out as described previously by Gulewicz and cols. [46]. Briefly, $100 \mathrm{~g}$ of defatted flour was extracted with $200 \mathrm{~mL}$ of $50 \%$ ethanol $(v / v)$ at $40{ }^{\circ} \mathrm{C}$ overnight. After extraction, the supernatant was decanted. The flour was reextracted with fresh $50 \%$ ethanol under the same conditions, and the supernatants from two cycles of extraction were combined. The clear supernatant was concentrated on a rotary vacuum evaporator (BÜCHI, Essen, Germany) at $50{ }^{\circ} \mathrm{C}$ to the volume of $25 \mathrm{~mL}$, placed in glass separator, and dropped into $100 \%$ ethanol with continuous stirring.

The ratio of water extract volume to volume of $100 \%$ ethanol should be 1:10. The crude raffinose family oligosaccharides (RFOs) precipitate was separated from supernatant by centrifugation at $3000 \mathrm{rpm}$ for $15 \mathrm{~min}$. The RFOs precipitate was then placed into a vacuum desiccator overnight in order to remove any ethanol residue. The proximate composition, protein, moisture, ether extract, ash, and crude fiber contents of the L. albus defatted flour were determined as described in the official methods of analysis from AOAC International.

\subsection{Animals}

Twenty eight-week-old male C57BL/6 mice weighing between 18 and $25 \mathrm{~g}$ were obtained from the University Center for Health Sciences (CUCS) Bioterium of the University of Guadalajara. The experimental animals were maintained in a standard laboratory, with the following standard conditions: $25^{\circ} \mathrm{C}$ temperature, $55.0 \pm 5 \%$ humidity, and a 12-h light-dark cycle with ad libitum access to water and a standard rodent diet (Purina LabDiet $^{\circledR}$ 5001). The ethics committee from the University Center of Health Sciences (CUCS), University of Guadalajara, approved this protocol with a registration number CI-00420 (approved on 14 February 2020). All animal procedures were conducted according 
to the production, care, and use of laboratory animals established in the Mexican Official Standard (NOM-062-ZOO-1999).

\subsection{Preparation of Dosage Alpha-Galactooligosaccharides and Treatment}

The dosage selection of Lupinus albus $\alpha$-galactooligosaccharides (LA-GOS), used in the treatment, was determined according to the literature [47-52]. To select the therapeutic dosage, we considered the following theoretical aspects: the evaluated experimental model, its demonstrated effect in the model, and the dosage conversion according to the selected species (mice model). Finally, we decided to use a $2.5 \mathrm{~g} / \mathrm{kg}-\mathrm{bw}$ per day dosage Figure S1. Therefore, LA-GOS treatment consisted of the daily oral administration of $2.5 \mathrm{~g} / \mathrm{kg}$-bw $/$ day of LA-GOS dissolved in $200 \mu \mathrm{L}$ of sterile water during fourteen consecutive days (from day 1 to 14$)$.

\subsection{Experimental Design}

Experimental ulcerative colitis induction in mice was performed by giving drinking water ad libitum containing 2\% (w/v) dextran sulfate sodium (DSS) $\mathrm{M}_{\mathrm{r}} \sim 40,000$ (\# 42867Sigma Aldrich, St. Louis, MO, USA) during seven consecutive days (from day 7 to 14) [53]. After one acclimation week, 20 mice were randomly distributed in four experimental groups $(n=5)$ : the control group (Healthy), the healthy treated group (Healthy + LA-GOS, $2.5 \mathrm{~g} / \mathrm{kg}$ bw/day)), the model group (untreated Ulcerative colitis-UC model), and the treated UC model group (UC + LA-GOS, $2.5 \mathrm{~g} / \mathrm{kg}$ bw /day).

Mice of the healthy and healthy + LA-GOS groups were given distilled water without DSS during the whole experimental period. The UC and UC + LA-GOS groups were induced into ulcerative colitis on the 7th day, for one week (from day 7 to 14). In the healthy + LA-GOS and UC + LA-GOS groups, the LA-GOS treatment was administered by oral gavage during 14th consecutive days, whereas the healthy and UC groups received only the vehicle of treatment (sterile water) by gavage for fourteen consecutive days.

After the experimental period, all mice were sacrificed on the 15 th day [48]. The mice were anesthetized, and blood was collected from the internal iliac vein. Euthanasia of the laboratory animals was performed by cervical dislocation. From each experimental animal, the colon was extracted from the cecum to rectum. In addition, the mesenteric tissue was removed from the colonic tissue. Then, the colon tissue was rinsed with normal saline solution $(0.9 \% w / v)$, and the colon length was measured and documented. Descending colon tissue was fixed immediately in 10\% formaldehyde in $1 \mathrm{X}$ phosphate buffer saline (PBS) to perform later histological analysis.

\subsection{Disease Activity Index (DAI)}

To evaluate the ulcerative colitis severity, the Disease Activity Index (DAI) was determined at UC basal day (day 7) and at the end of the experiment (day 14). The DAI was calculated based on the clinical signs scoring including weight loss, stool character, and the presence of blood in the feces Table 1 [54].

Table 1. Disease Activity Index (DAI).

\begin{tabular}{ccll}
\hline Score & Weight Loss & Stool Consistency & Blood in Feces \\
\hline 0 & 0 & Normal & Negative \\
1 & $1-5 \%$ & Soft but still formed & Thimbleful, blood steak \\
2 & $5-10 \%$ & Sof and unformed & Modicum, blood Clot [54] \\
3 & $10-20 \%$ & Lose & Visible bloody stool \\
4 & $>20 \%$ & Diarrhea & Gross bleeding \\
\hline & & Taken from Ref. [54]
\end{tabular}

\subsection{Histopathological Analysis}

The descending colon tissue was excised, washed in saline solution, fixed in $10 \%$ formaldehyde in 1X phosphate buffer saline (PBS), embedded in paraffin, and sectioned 
(5 $\mu \mathrm{m}$ thick). Later, the colonic tissue was stained for seven minutes with Mayer's Hematoxylin (HYCEL, Zapopan, Mexico) and then with 0.2\% eosin (HYCEL, Zapopan, Mexico) for one minute. The severity of the epithelial damage was evaluated by a certified pathologist with the following criteria Table 2 [55]:

Table 2. Scoring scheme for chemically induced colonic inflammation.

\begin{tabular}{|c|c|c|c|c|c|}
\hline \multicolumn{2}{|c|}{ Inflammatory Cell Infiltrate } & \multirow{2}{*}{ Score 1} & \multicolumn{2}{|c|}{ Intestinal Architecture } & \multirow{2}{*}{ Score 2} \\
\hline Severity & Extent & & Epithelial change & Mucosal architecture & \\
\hline Mild & Mucosa & 1 & Focal erosion & & 1 \\
\hline Moderate & $\begin{array}{l}\text { Mucosa and } \\
\text { Submucosa }\end{array}$ & 2 & \multirow{3}{*}{ Erosions } & $\begin{array}{l} \pm \text { Focal } \\
\text { Ulcerations }\end{array}$ & 2 \\
\hline Market & Transmural & 3 & & $\begin{array}{l}\text { Extended ulcerations } \pm \text { granulation } \\
\text { tissue } \pm \text { pseudopolyps }\end{array}$ & 3 \\
\hline \multicolumn{5}{|c|}{ Total sum of score 1 and $2=0$ to 6} & \\
\hline Taken Fron & & & & & \\
\hline
\end{tabular}

\subsection{Goblet Cells Count}

Paraffin blocks of the descending colon tissue were cut into $5 \mu \mathrm{m}$ sections. For each sample, one slide containing five tissue sections was prepared. The sections were stained with Alcian blue (HYCEL, Zapopan, Mexico) and counterstained with hematoxylin to visualize the goblet cells. The number of goblet cells per each sample was obtained from three randomly selected sections of colonic epithelium. From each selected section, ten crypts were randomly chosen (30 crypts in total, per sample). The goblet cells quantity was measured using the viewing APERIO Image Scope software (https: / / www.leicabiosystems.com/es/patologia-dig ital/gestion/aperio-imagescope/) by LEICA with a $20 \times$ magnification $(100 \mu \mathrm{m})$. Therefore, the number of goblet cells was expressed as "number of goblet cells per crypt per $100 \mu \mathrm{m}$ " [56,57].

\subsection{Feces Protocol}

The fecal samples were collected on the 14th day in all experimental groups. To guarantee a homogeneous quality of the sample, all fresh fecal samples were collected in sterile tubes, and immediately after, frozen in dry ice and stored at $-80^{\circ} \mathrm{C}$ until analysis. In the same manner, before the sacrifice of the animals (15th day), the feces from cecum were collected in sterile tubes and immediately frozen in dry ice and stored at $-80{ }^{\circ} \mathrm{C}$ until analysis [58].

2.9. Relative Abundance of Microbial Phyla and Butyryl CoA Transferase Using Semiquantitative Real-Time PCR

To quantify the microbial phyla and butyryl-CoA transferase gene positive bacteria, genomic DNA was extracted from $25 \mathrm{mg}$ of fecal samples of the 14th day using a QuickDNA Fecal/Soil kit (Zymo Research, Irvine, CA, USA) according to the manufacturer's instructions. DNA concentrations were measured by nanodrop (Thermo Fisher Scientific, Waltham, MA, USA). The quantification via real-time PCR was performed using Maxima SYBR Green Master Mix (Thermo Fisher Scientific, \#K0251, Waltham, MA, USA). All experiments were realized with the StepOne Thermocycler (Applied, Biosystem, Waltham, MA, USA).

Primers 27F: 5'-AGAGTTTGATCMTGGCTCAG-3' and 519R: 5'-GWATTACCGCGGC KGCTC-3' were used to amplify the V3 to V4 regions of the $16 \mathrm{~S}$ rDNA of total bacteria [59]. The reaction was performed under the following conditions: hold $95^{\circ} \mathrm{C}(7 \mathrm{~min})$ followed by 25 cycles of $95^{\circ} \mathrm{C}(30 \mathrm{~s}), 60^{\circ} \mathrm{C}(50 \mathrm{~s})$, and $72{ }^{\circ} \mathrm{C}$ (40 s). To determine the microbiota phyla, the used primers were: Firmicutes Firm934F: $5^{\prime}$-GGAGYATGTGGTTTAATTCGAAGCA-3 ${ }^{\prime}$ and Firm1060R: 5'-AGCTGACGACAACCATGCAC3'. Bacteroidetes Bact934F: 5'-GGAGYATGT GGTTTAATTCGAAGCA-3' Bact1060R: $5^{\prime}$ AGCTGACGACAACCATGCAG-3' [60]. Proteobacteria F: 5’ TCGTCAGCTCGTGTYGTGA-3' and R: 5' CGTAAGGGCCATGATG-3' [61]. 
Reactions were realized under the following conditions: hold $95{ }^{\circ} \mathrm{C}(10 \mathrm{~min})$, followed by 35 cycles of $95^{\circ} \mathrm{C}(30 \mathrm{~s})$, alienation temperature Firmicutes $69^{\circ} \mathrm{C}$, Bacteroidetes $67^{\circ} \mathrm{C}$, and Proteobacteria $63{ }^{\circ} \mathrm{C}(1 \mathrm{~min})$ and $72{ }^{\circ} \mathrm{C}(40 \mathrm{~s})$ of extension for all phyla. In addition, Butyryl-CoA transferase gene positive bacteria were amplified using the following primers BCoATsxrF: 5'-GCIGAICATTTCACITGGAAYWSITGGCAYATG and BCoATscrR: $5^{\prime}$-CCTGCCTTTGCAATRTCIACRAANGC-3' [62]. The analysis was done under the following experimental conditions: hold $95^{\circ} \mathrm{C}(5 \mathrm{~min})$, followed by 40 cycles of $95^{\circ} \mathrm{C}(30 \mathrm{~s})$, $53{ }^{\circ} \mathrm{C}(30 \mathrm{~s})$, and $72{ }^{\circ} \mathrm{C}(30 \mathrm{~s})$.

All primer sequences were analyzed by the BLAST program of the National Center for Biotechnology Information, to verify the correct alignment with the target. Relative quantification of PCR products was determined with the $2^{\Delta \Delta C t}$ method [63]. The analysis of $16 \mathrm{~s}$ rDNA for total bacteria was used as a reference gene. For each analyzed gene, a melting curve analysis was performed to confirm amplicons.

\subsection{Short Chain Fatty Acids Quantification}

For the SCFAs quantification, $25 \mathrm{mg}$ of feces from the cecum of each sample were weighed in a sterile tube, and $200 \mu \mathrm{L}$ of sterile distilled water was added and homogenized. The next step was added to the homogenate $200 \mu \mathrm{L}$ of the solution prepared with N-butanol, tetrahydrofuran, and acetonitrile in a 50:30:20 ratio. After that, it was aggregated with $40 \mu \mathrm{L} \mathrm{HCl} \mathrm{0.1M,} 20 \mathrm{mg}$ citric acid, and $40 \mathrm{mg}$ of $\mathrm{NaCl}$. All the components were mixed until their homogenization. The supernatant was obtained by centrifugation at $13,000 \times g$ for $10 \mathrm{~min}$.

The supernatant was filtered with a Whatman GD/X syringe filter $0.22 \mu \mathrm{m}$ of PVDF (MERCK, Billerica, MA, USA). Afterwards, the supernatant was analyzed in a Shimadzu GC 2010 plus gas chromatograph with a flame ionization detector (FID) (Shimadzu Scientific Instrument, Kyoto, Japan). To perform the analysis, a high polarity stationary phase column (Mega-Acid) was used, with the following characteristics: $30 \mathrm{~m} \times 0.25 \mathrm{~mm}$ of intern diameter (id) and thickness: $0.40 \mu \mathrm{m}$.

The conditions of analysis were injection $3 \mu \mathrm{L}$, split 1:25, oven temperature $250{ }^{\circ} \mathrm{C}$, detector temperature $250{ }^{\circ} \mathrm{C}$, gas flow: $\mathrm{N}_{2} 30 \mathrm{~mL} / \mathrm{min}, \mathrm{H}_{2} 40 \mathrm{~mL} / \mathrm{min}$, and air $400 \mathrm{~mL} / \mathrm{min}$. The data were analyzed with the LabSolutions, Chromatography Data System software (Shimadzu Scientific Instruments, Kyoto, Japan). In addition, the quantifications of each acid (acetic acid, butyric acid, and propionic acid) were analyzed with a standard curve of six points $(100,50,25,12.5,6.25$, and $3.125 \mathrm{ppm})$. The concentration of SCFAs in each sample was determined by the interpolation of the data with the standard curve [64].

\subsection{1. pH Measurement}

In each sample, the $\mathrm{pH}$ value was measured in feces collected from the cecum. For the preparation of the sample, $50 \mathrm{mg}$ of feces were weighed in a $500 \mu \mathrm{L}$ sterile tube, and $200 \mu \mathrm{L}$ of sterile water was added and vortexed for $2 \mathrm{~min}$ [65]. The $\mathrm{pH}$ level was determined using a pre-calibrated potentiometer with a ROSS BNWP 8220 microelectrode (Thermo Fisher Scientific, Waltham, MA, USA). This electrode is specifically designed for the $\mathrm{pH}$ measurement of small volumes and in dirty samples, such as feces.

\subsection{Immunohistochemistry}

The Claudin-1 protein expression was determined in descending colon tissue. The resected tissue was fixed immediately with 10\% formaldehyde in 1X phosphate buffer saline (PBS), processed and embedded in paraffin. Paraffin-embedded samples were cut, and sections $(3 \mu \mathrm{m})$ were treated with the Novolink polymer detection system according to the manufacturer's instructions. Antigen retrieval was performed with EDTA buffer (1 mM EDTA, 0.05\% Tween 20, and $\mathrm{pH} 8.0$ ) for $40 \mathrm{~min}$.

Sections were incubated overnight at $4{ }^{\circ} \mathrm{C}$ with a mouse monoclonal primary antibody (sc-166338, Santa Cruz Biotechnology, Danvers, MA, USA) at a 1:250 dilution. Adipose tissue was used as a negative control. Finally, the chromogen working solution and 
hematoxylin were used to perform the detection and counterstain, respectively. The claudin-1 expression was documented using the Aperio LV1 IVD equipment and Aperio imagescope software (Leica Biosystem, Chicago, IL, USA). The staining intensity was scored as follows: $0=$ negative, $1=$ weak, $2=$ moderate, and $3=$ strong [66].

\subsection{Statical Analysis}

Data are presented as the mean \pm standard error of the mean (SEM) for the relative abundance of microbiota phyla and butyryl-CoA transferase gene. The DAI score, Length colon, histopathological score, number of goblet cells, staining intensity score, SCFAs, and $\mathrm{pH}$ levels data are expressed as the mean \pm standard deviation (SD). The Brown-Forsythe test was performed to evaluate the change in the relative abundance of Bacteroidetes, Proteobacteria-phyla and butyryl-CoA transferase genes. The Kruskal-Wallis test was utilized to assess the expression of claudin-1. In addition, one way ANOVA was employed to analyze the DAI, length colon, histopathological score, number of goblet cells, total bacteria, Firmicutes phylum, SCFAs concentrations, and $\mathrm{pH}$ levels. All statistical analyses were performed with the GraphPad Prism software (version 8.0, San Diego, CA, USA). A $p$ value $\leq 0.05$ was considered significant.

\section{Results}

\subsection{LA-GOS Treatment Ameliorates the Clinical Characteristics of Ulcerative Colitis}

As shown in Figure 1a, the Disease Activity Index (DAI) was reduced by $50 \%$ after LA-GOS treatment in the UC model in comparison with the untreated UC group. The colon length was similar in the healthy and healthy + LA-GOS experimental groups $(9.2 \pm 0.15 \mathrm{~cm}$ and $9.6 \pm 0.3 \mathrm{~cm}$, respectively) (Figure 1b,c). As expected, the colon length in the UC group was significantly reduced in comparison with the healthy group $(8.3 \pm 0.45 \mathrm{~cm}$ vs. $9.2 \pm 0.15 \mathrm{~cm}, p<0.001)$. On the contrary, the colon length in the $\mathrm{UC}+\mathrm{LA}-\mathrm{GOS}$ group remained a comparable length as the healthy group $(9.12 \pm 0.13 \mathrm{vs}$. $9.2 \pm 0.15 \mathrm{~cm}$ ) (Figure 1b,c). We can suggest that the LA-GOS treatment prevented the shortening of the colon, which was evident when comparing the treated and untreated UC groups (9.12 \pm 0.13 vs. $8.3 \pm 0.45 \mathrm{~cm}, p \leq 0.01)$.

\subsection{LA-GOS Administration Reduced the Histopathological Colon Damage and Increased the Goblet Cell Number}

Histopathological changes in colitis were analyzed and scored in the descendent colon tissue. Representative H\&E-stained histological sections as well as the histopathological score are shown in Figure $2 \mathrm{a}-\mathrm{d}$,i. The colon from both, healthy and healthy + LA-GOS groups, showed healthy epithelium, that means the presence of well-organized crypts, non-infiltration in mucosa and submucosa, and no ulceration or tissue erosion.

In contrast, the colon epithelium from the UC group developed severe inflammatory lesions, characterized by complete loss or crypts, surface erosion, and extensive diffuse ulceration as well as mucosa and submucosa infiltrates $(p \leq 0.0001)$. Notably, the $\mathrm{UC}+$ LA-GOS group exhibited a significant reduction in inflammation and colon injury. After treatment, we observed mild inflammation, preservation of the majority of crypts, surface erosion, and only focal ulceration and infiltrates uniquely in mucosa $(p \leq 0.0005)$. Based on the histopathological score, LA-GOS treatment improves the intestine health in comparison with the untreated UC group $(p \leq 0.01)$.

We use the Alcian staining in order to visualize the goblet cells, and after that these cells exhibit a blue color. Alcian-positive cells were observed inside of the crypts from descending colonic tissue (Figure $2 \mathrm{e}-\mathrm{g}$ ). A semiquantitative analysis of the goblet cell number per crypt was performed and is shown in Figure $2 \mathrm{j}$. As described in the literature [67], the goblet cell number was significantly reduced after the DSS-induced colitis model (44\% in comparison with the healthy group, $p \leq 0.0001)$. On the other hand, LAGOS treatment increased the goblet cell number by $25 \%$ in the UC model compared to the untreated UC group ( $p \leq 0.005)$. These results show that LA-GOS treatment prevented the 
reduction of goblet cells, and this indicates that the mucosal damage could be attenuated in ulcerative colitis.

(a) Disease Activity Index

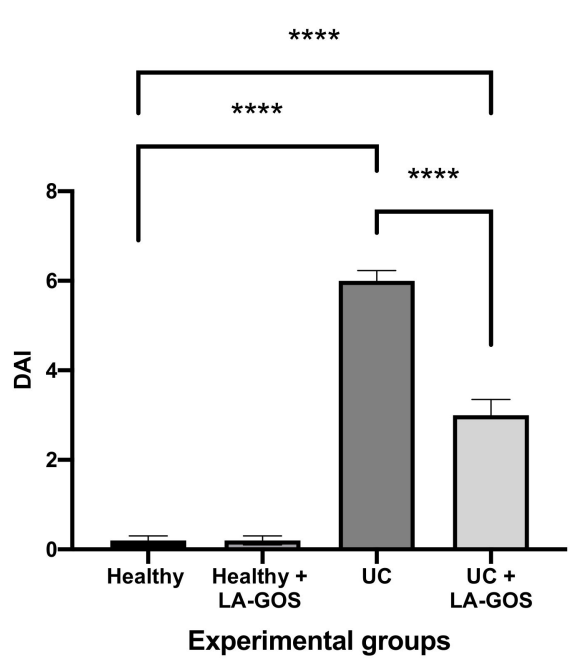

(b) Length Colon

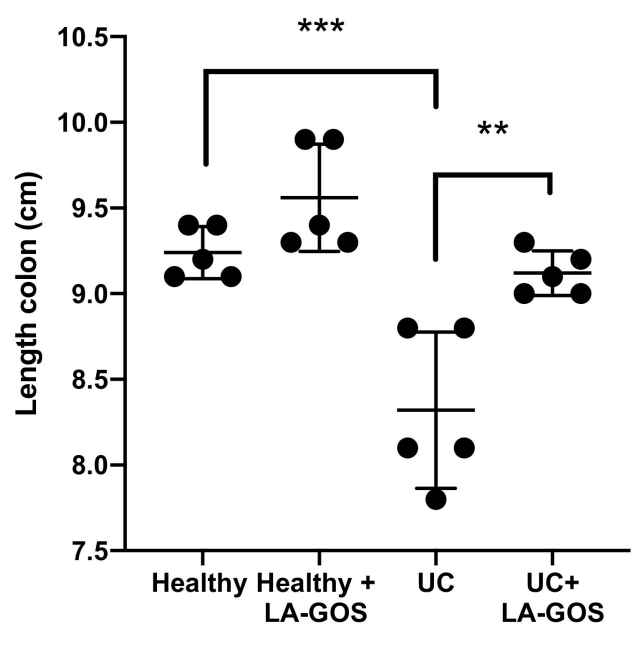

Experimental groups

(c) Length Colon Images

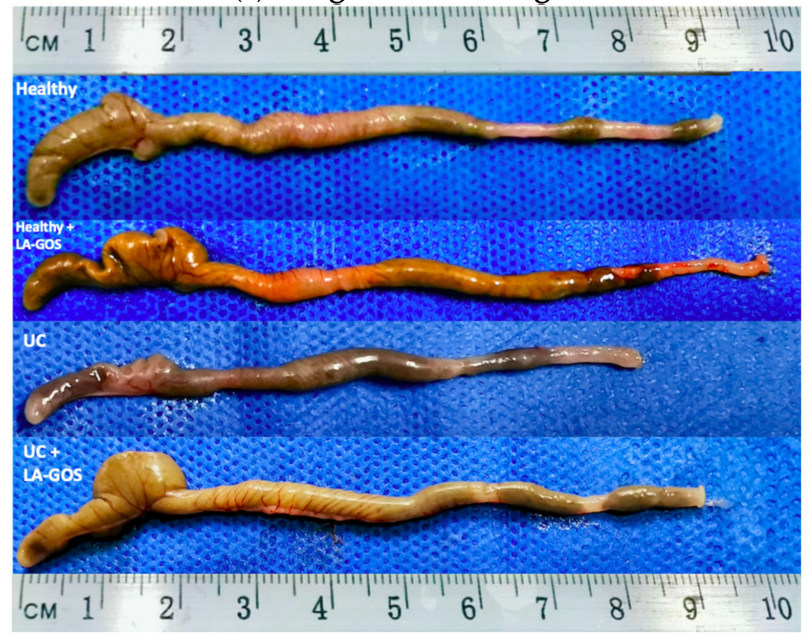

Figure 1. (a) The disease activity index (DAI) was determined as the average of the score of weight loss, stool consistency, and bleeding at the 14th day (previously described). The mean value of DAI was significantly different when the UC and UC + LA-GOS groups were compared to the healthy group. Indeed, UC + LA-GOS significantly reduced the DAI in comparison to the UC group. (b) Length of the colon (cecum until rectum) is represented in $\mathrm{cm}$. Differences were found between the healthy and UC groups. In fact, the LA-GOS treatment increased the length colon of UC induced animals when they were compared against the untreated UC group. (c) Representative images of the colons from each experimental group are shown. Data are expressed as the mean $\pm \mathrm{SD}$. A one-way ANOVA test was used to analyze the DAI and length colon data, followed by Dunnett's comparison test. ${ }^{* *} p \leq 0.01,{ }^{* * *} p \leq 0.001$, and $\left.{ }^{* * *} p \leq 0.0001\right)$. 


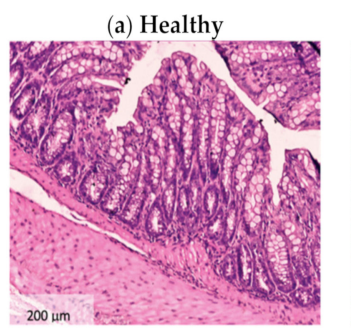

(e)

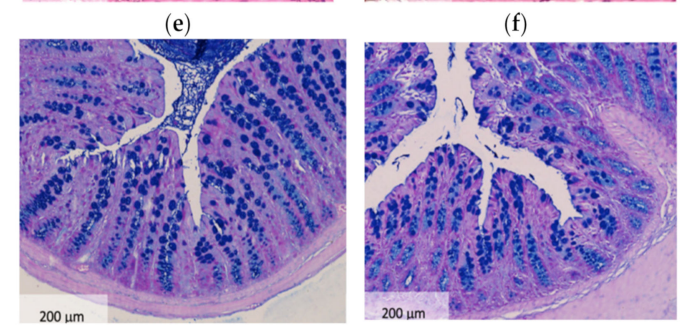

(i) Histopathological score

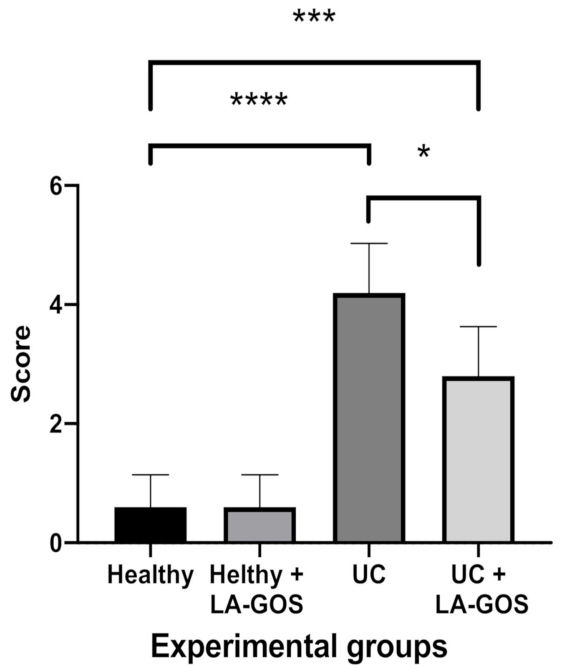

(b) Healthy + LA-GOS

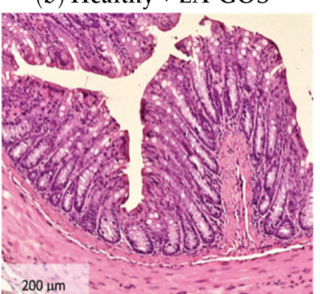

(f)

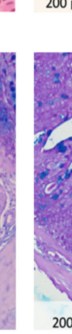

(c) UC

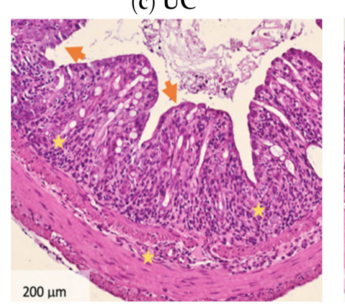

(g)

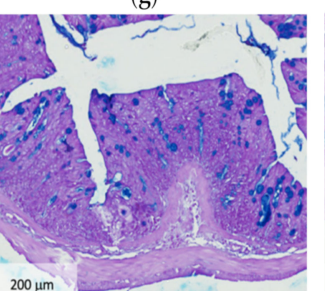

(j) Number of Goblet cells

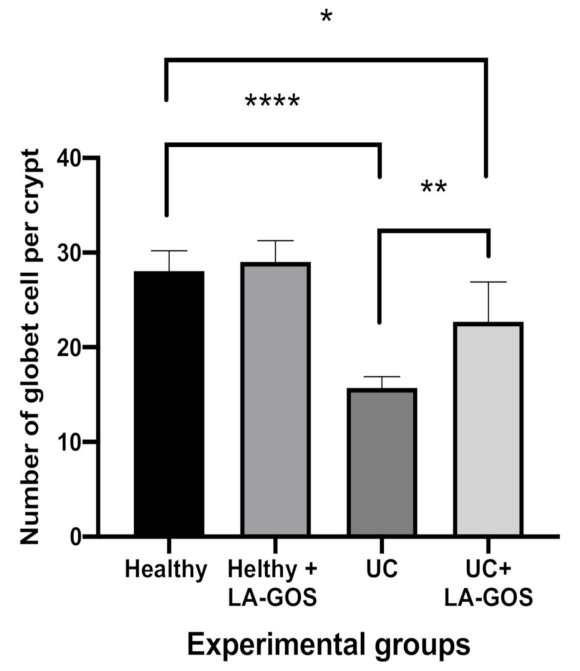

Figure 2. Histological images stained with H\&E (a-d) and Blue Alcian (e-h) representing each experimental group are shown $(\times 10$ magnification, bar= $200 \mu \mathrm{m}) .(\mathbf{a}, \mathbf{e})$ Healthy group, $(\mathbf{b}, \mathbf{f})$ Healthy + LA-GOS, (c,g) Ulcerative Colitis (UC), and (d,h) UC + LA-GOS. (a,b) Healthy and healthy + LA-GOS showed normal histological characteristics. (c) UC group showed severe inflammatory cells in the mucosa and submucosa (yellow stars) and erosion (orange arrows) in the descendent colon. LA-GOS administration attenuated DSS-induced microscopic colon damage. (d) Inflammatory cells in mucosa (yellow stars) and erosion (orange arrows). The evaluation of the goblet cell number was normal $(\mathbf{e}, \mathbf{f})$, on the contrary, a loss of goblet cells was observed in the UC group (g). After LA-GOS treatment, the number of goblet cells was improved (h). A semiquantitative analysis was performed to evaluate the histopathological score (i) and the number of goblet cells per crypt (j). Semiquantitative analysis revealed differences in the mean value of the histopathological score among UC, UC + LA-GOS and healthy groups. Moreover, UC + LA-GOS significantly reduced the histopathological score in comparison to the UC group. Differences in the number of goblet cells per crypt were found between healthy and UC groups. In addition, the LA-GOS treatment augmented the goblet cell number in comparison with those found in the untreated UC group. Data are exhibited as the mean $\pm \mathrm{SD}$. A one-way ANOVA test was used to evaluate the histopathological score and the number of goblet cells, followed by Dunnett's multiple comparison test. ${ }^{*} p \leq 0.01,{ }^{* *} p \leq 0.005$, *** $p \leq 0.0005$, and $\left.{ }^{* * * *} p \leq 0.0001\right)$.

\subsection{Claudin-1, a Tight Junction Protein, Is Reduced in DSS-Induced Acute Colitis}

In order to understand the effect of administration of LA-GOS treatment on the expression of tight junctions, claudin-1 Inmunohistochemistry was performed in descending colon tissue (Figure 3a-e). The Claudin-1 expression was significantly decreased in both UC 
groups in comparison with the healthy group ( $p \leq 0.05$ and $p \leq 0.005)$. LA-GOS treatment shows a tendency to recover the claudin- 1 expression in the treated UC group $(20 \%$ more than the untreated group, without significance).

(a) Healthy

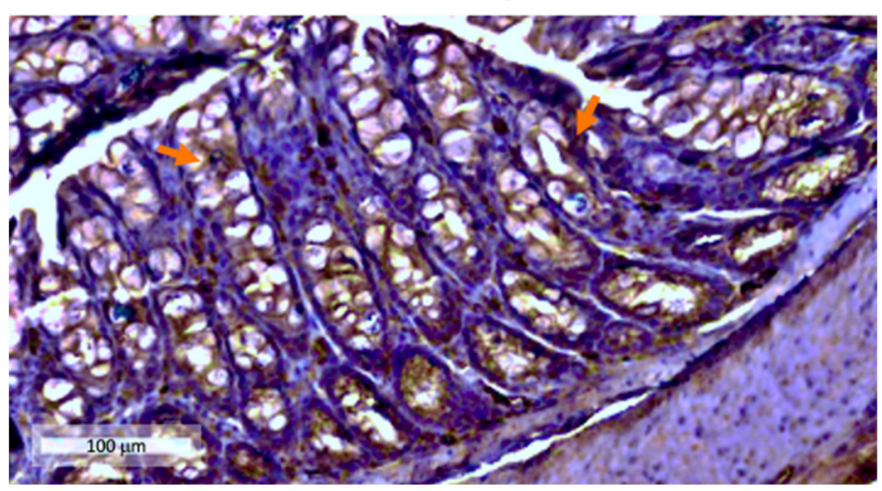

(c) UC

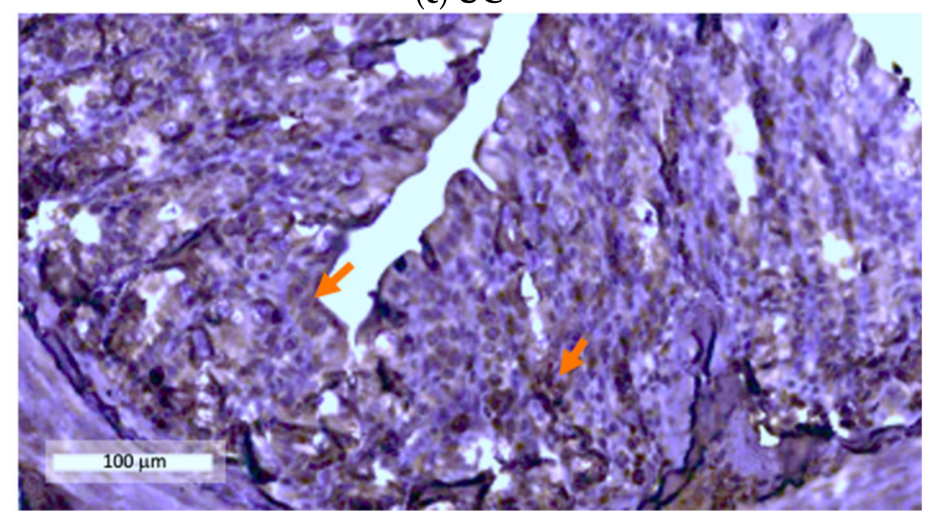

(b) Healthy + LA-GOS

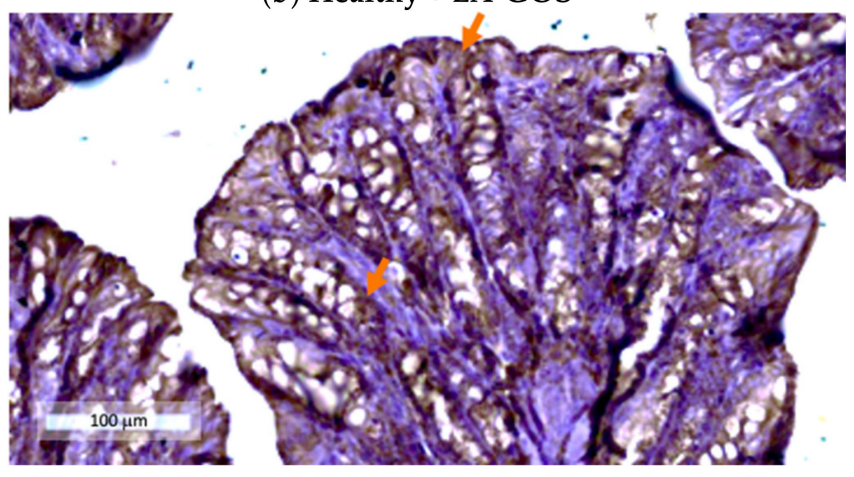

(d) UC + LA-GOS

(e) Staining intensity score
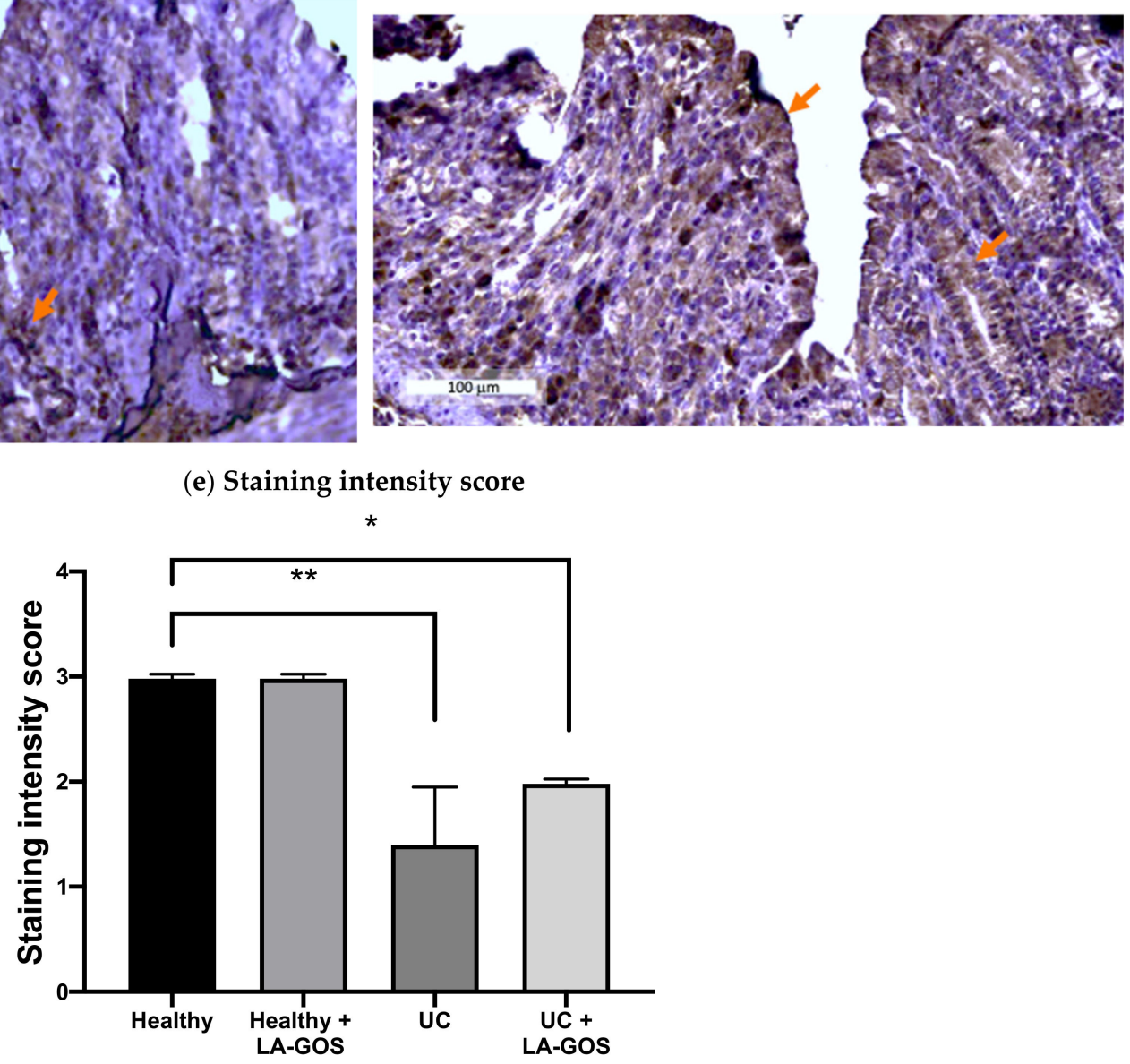

Experimental groups

Figure 3. Immunohistochemistry (IHC) was performed for the expression of the claudin-1 protein in the descendent colon tissue of each experimental group. (a-d) Representative images for claudin-1 counterstained with Hematoxylin are shown $(\times 20$. magnification, bar $=100 \mu \mathrm{m})$. Claudin-1 is localized at the crypt surface and basolateral membrane (orange arrows) (a) Healthy, (b) Healthy + LA-GOS, (c) Ulcerative colitis (UC), (d) UC + LA-GOS. In the healthy and healthy + LA-GOS groups was found a normal expression of claudin-1 $(\mathbf{a}, \mathbf{b})$, whereas, in the UC and UC + LA-GOS groups, the expression decreased (c,d). (e) Semiquantitative score of claudin 1 protein levels. Data are expressed as the mean $\pm \mathrm{SD}$. Semiquantitative analysis revealed differences in the mean value of the immunohistochemistry score among UC and UC + LA-GOS vs. healthy group. The Kruskal-Wallis test was used to compare the claudin-1 IHC score followed by Dunn's test. ( $p \leq 0.05$ and ${ }^{* *} p \leq 0.005$ ). 


\subsection{Gut Microbiome Shift in Mice with DSS-Induced Acute Colitis and Treated with LA-GOS}

To further explore the protective effect of LA-GOS treatment, we quantified the gut microbiota by real-time PCR. The relative abundance of total bacteria was determined by the 16s rDNA gene. In our study, we found a significant reduction of the total bacteria in both UC groups in comparison with the healthy group $\left({ }^{*} p \leq 0.05\right.$ and ${ }^{* *} p \leq 0.005$, respectively). However, LA-GOS treatment exerts a $19 \%$ gain of the relative abundance of total bacteria when compared with the untreated UC group Figure 4a. Moreover, we determined the relative abundance of the Bacteroidetes phylum with significant differences between the healthy group and both UC groups $\left(* p \leq 0.05,{ }^{* * *} p=0.001\right)$ Figure $4 \mathrm{~b}$.

Interestingly, we observed that LA-GOS treatment increased, by $30 \%$, the relative abundance of the Bacteroidetes phylum in the UC + LA-GOS group when it was compared against the untreated UC group. With respect to the Proteobacteria phylum, LA-GOS treatment reduced the relative abundance of the Proteobacteria phylum in UC conditions Figure 4c (data not significant). Finally, when we evaluated the Firmicutes phylum, LAGOS treatment increased the relative abundance by $110 \%$ in comparison with the UC untreated group $\left.{ }^{* *} p=0.01\right)$. All these results show the promissory effect of LA-GOS as a gut microbiota modulator.

\subsection{LA-GOS Increased the Proportion of Butyryl-CoA Transferase Gene Positive Bacteria in the} Healthy Group

Butyryl-CoA transferase is the most important pathway utilized by the gut microbiota to the production of Butyric acid [68]. In our study, we evaluated the effect of LA-GOS treatment on the relative abundance of bacteria, which contain the butyryl CoA transferase $(B u t)$ gene. In a healthy condition, we found that LA-GOS treatment significantly increases the abundance of But gene positive bacteria $(p \leq 0.01)$. By contrast, under the UC environment, the abundance of positive bacteria to the But gene is reduced. Nevertheless, after LA-GOS treatment in these conditions, it was not possible to restore the initial But positive bacteria number (Figure 5).

\subsection{LA-GOS Modified the Production and Pattern of Short Chain Fatty Acids}

SCFAs are the main metabolites produced by the gut microbiota that participate in the intestinal health regulation [7]. To investigate the impact of LA-GOS treatment on SCFAs, we decided to quantify the acetic, propionic, and butyric acid concentrations as well as the total SCFA levels. We found that the LA-GOS treatment did not modify the SCFA total levels or the acetic acid production (Figure $6 \mathrm{a}, \mathrm{b}$ ). However, in the UC + LA-GOS group, we observed a tendency to increase the acetic acid concentration.

On the other hand, the UC + LA-GOS group showed significant lower propionic acid levels when it was compared with the healthy and UC groups $(27 \%$ and $23 \%$ of reduction, respectively) (Figure $6 c,{ }^{*} p=0.01$ and ${ }^{* *} p=0.005$ ). Added to that, the butyric acid concentration was significantly augmented after LA-GOS administration in the treated healthy group $\left(^{*} p=0.05\right)$, and a tendency to increase these levels was only observed in the UC + LA-GOS group (Figure 6d).

\subsection{Treatment with LA-GOS Decreased Fecal Cecum $p H$ Values}

Intestinal bacteria utilize the undigested fiber such GOS to generate SCFAs [69]. The SCFA production has been related with the intestinal $\mathrm{pH}$ levels [7]. In this study, we measured the intestinal $\mathrm{pH}$ from the cecum feces in all experimental groups. Our results showed a reduction on the $\mathrm{pH}$ levels when LA-GOS treatment was administered (Figure 7). Notably, we found a significant difference when $\mathrm{pH}$ values were compared between both healthy groups $(7.54 \pm 0.29$ versus $6.76 \pm 0.06, p \leq 0.001)$. In the same manner, the $\mathrm{UC}+\mathrm{LA}-\mathrm{GOS}$ group also exhibits a lower $\mathrm{pH}$ in comparison with the untreated UC group $(6.83 \pm 0.09$ versus $7.40 \pm 0.33, p \leq 0.005)$. We demonstrate that the LA-GOS treatment promoted a lower $\mathrm{pH}$ in feces, which is related with the SCFA production and intestinal colonic health [69]. 
(a) Total Bacteria

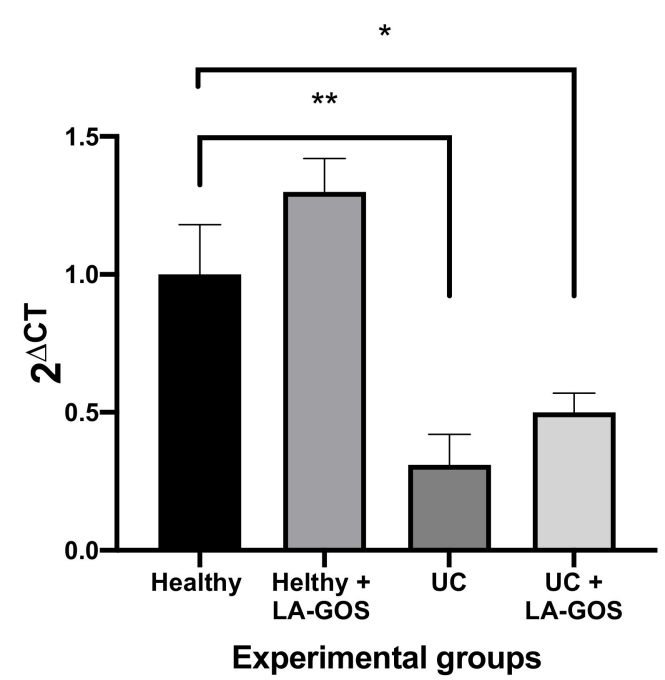

(c) Proteobacteria

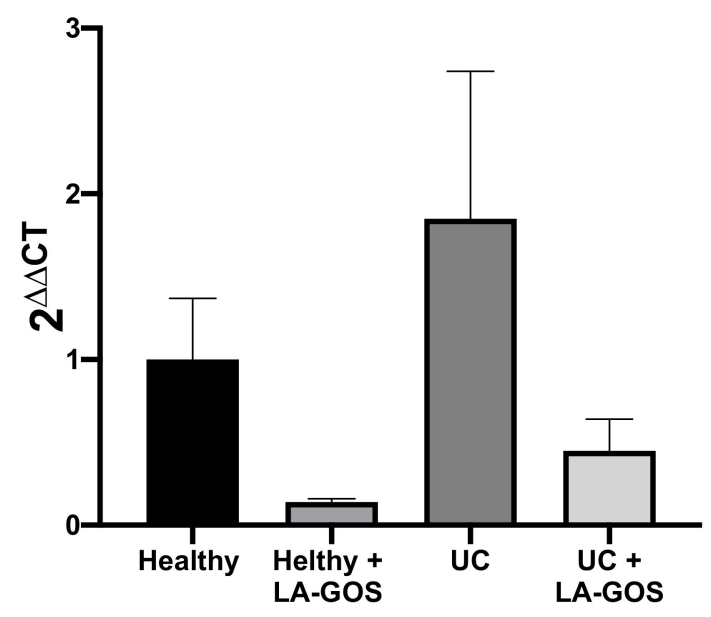

Experimental groups (b) Bacteroidetes

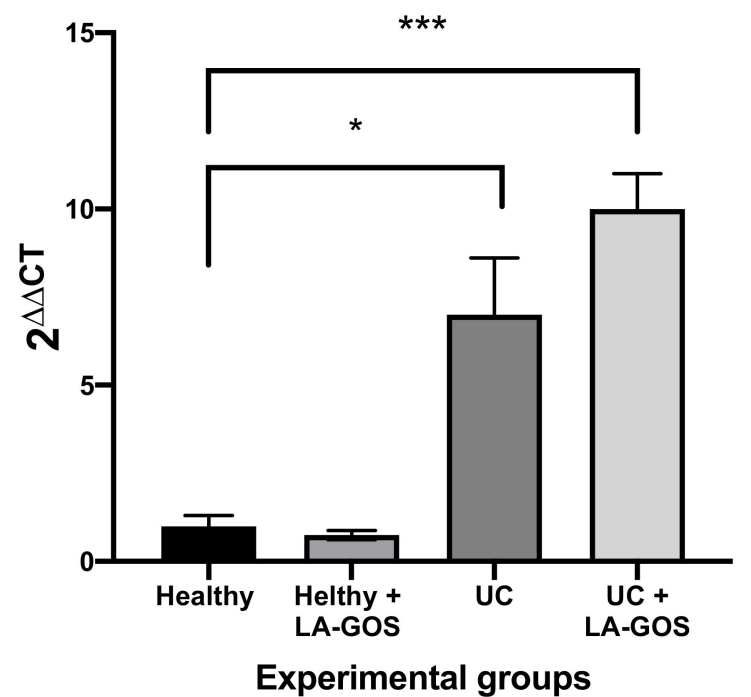

(d) Firmicutes

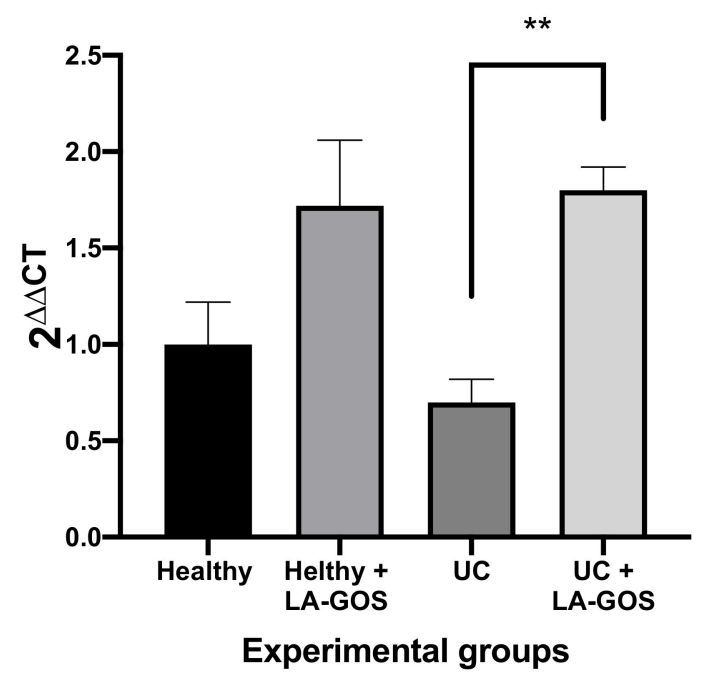

Figure 4. Intestinal microbiota were analyzed to determine the proportion of total bacteria and the proportion of the phyla-Bacteroidetes, Proteobacteria, and Firmicutes in feces at 14th day. Relative quantification (real-time PCR) of the total bacteria was performed by $16 \mathrm{~s}$ rRNA analysis $\left(2^{\Delta \mathrm{CT}}\right.$ ). Each phylum proportion was calculated by $2^{\Delta \Delta \mathrm{CT}}$ analysis between total bacteria and specific phylum. (a) Relative abundances of the total bacteria. Statical differences were found between heathy and UC groups. (b) Relative abundance of the Bacteroidetes phylum. The mean values of Bacteroidetes were significantly different when UC and UC + LA-GOS groups were compared against to the healthy group. (c) Relative abundance of the Proteobacteria phylum. The healthy + LA-GOS and UC + LA-GOS groups showed a tendency to decrease the proportion of Proteobacteria phylum; however, these differences were not statically significant. (d) Relative abundance of the Firmicutes phylum. LA-GOS treatment significantly increased the proportion of Firmicutes in the UC treated group. Results are expressed as the mean \pm SEM. One way ANOVA was performed to analyze the total bacteria and Firmicutes phylum, followed by the Dunnett's multiple comparison test ${ }^{*} p=0.05$ and $\left.{ }^{* *} p=0.005\right)$. The Brown-Forsythe test was performed to analyze the phyla Bacteroidetes and Proteobacteria, followed by Dunnett's T3 multiple comparison test. $\left({ }^{*} p \leq 0.05,{ }^{* *} p=0.01\right.$, and $\left.{ }^{* * *} p=0.001\right)$. 


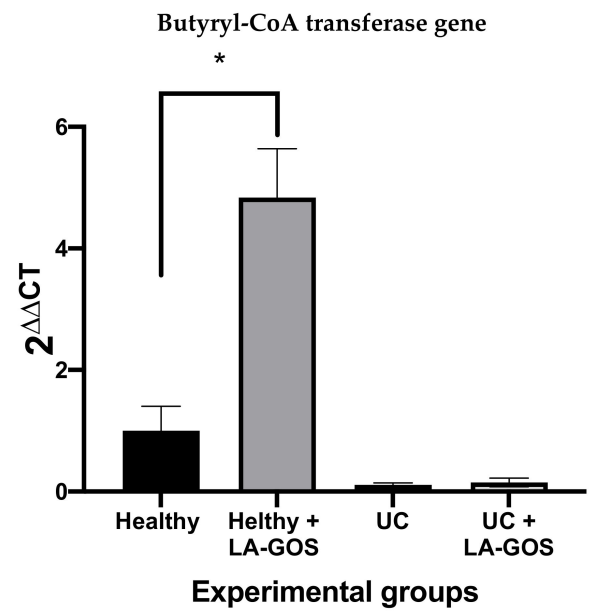

Figure 5. The Butyryl-CoA transferase (But) gene was quantified in the total bacteria in feces at the 14th day. The But gene was relative quantified using $2^{\Delta \Delta C T}$ analysis. Data analysis revealed significant differences between the healthy and healthy + LA-GOS groups. The results are expressed as the mean $\pm \mathrm{SEM}$. The Brown-Forsythe test was performed to analyze the data, followed by Dunnett's T3 multiple comparison test $\left({ }^{*} p \leq 0.01\right)$.

(a) Total SCFAs

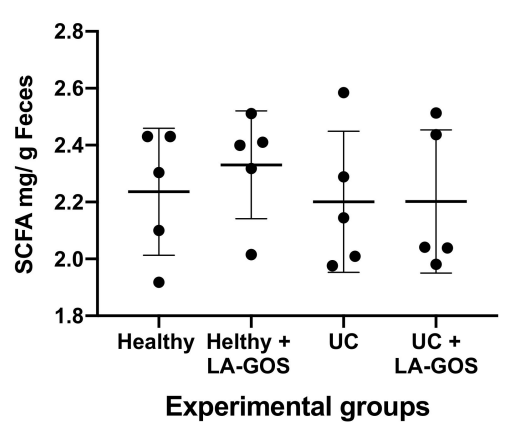

(c) Propionic Acid

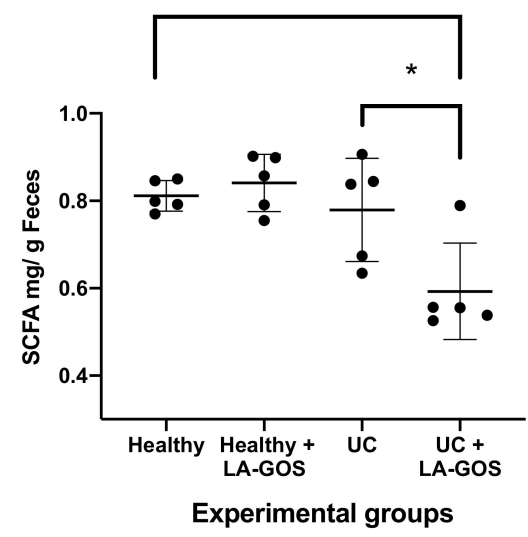

(b) Acetic Acid

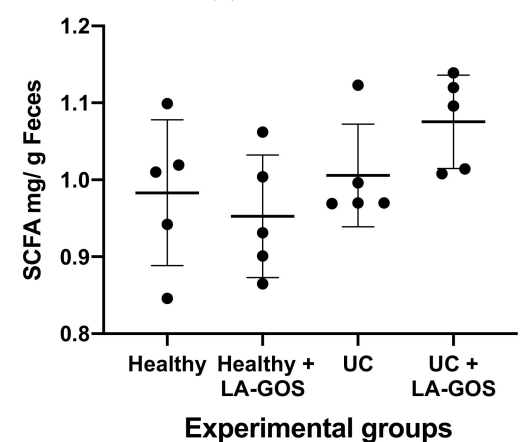

(d) Butyric Acid

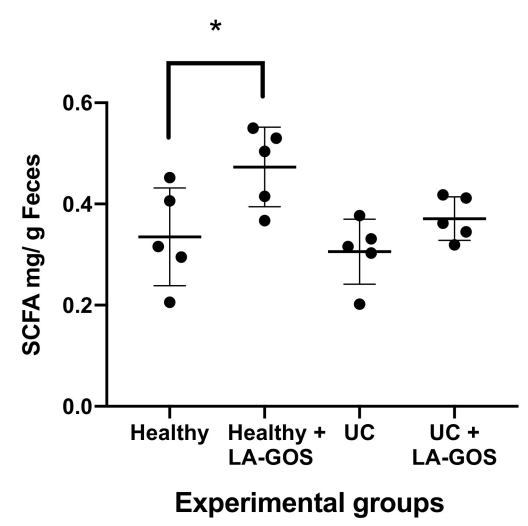

Figure 6. Short Chain Fatty Acid (SCFA) production was evaluated in the groups with and without LAGOS treatment. The concentration of SCFAs was measured in cecum stool samples of each experimental group. SCFA concentration values are expressed as SCFA mg per gram of feces. (a) Total SCFAs, (b) Acetic Acid, (c) Propionic Acid, (d) Butyric Acid. LA-GOS treatment reduced the propionic acid level when compared the healthy and UC + LA-GOS. Indeed, the LA-GOS treatment reduced the propionic acid level when was compared against untreated UC group. On the other hand, the production of butyric acid increased in the healthy + LA-GOS group in comparison with the healthy untreated group. Data are expressed as the mean $\pm \mathrm{SD}$. Mean values were compared using one way ANOVA followed by Dunnett's multiple comparison tests. $\left.{ }^{*} p \leq 0.05,{ }^{* *} p=0.005\right)$. 


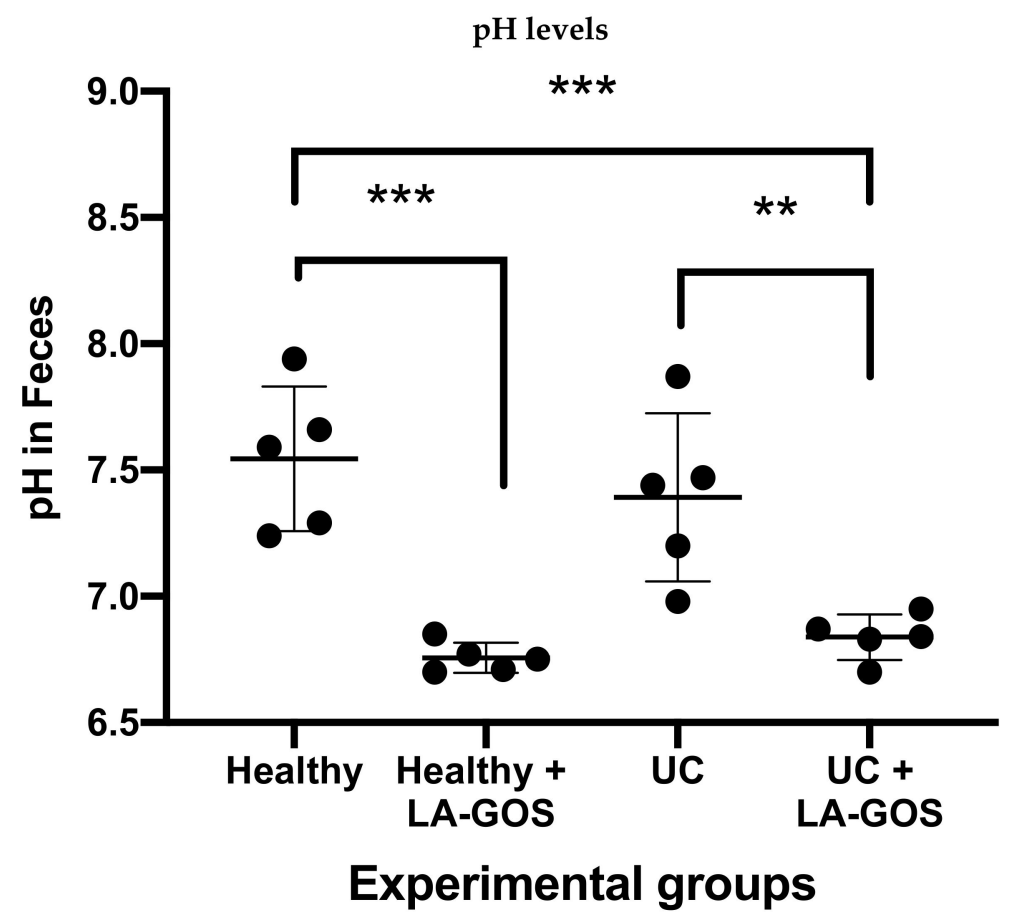

Figure 7. The measurement of $\mathrm{pH}$ was performed from cecum stool samples in each experimental group. LA-GOS treatment reduced the $\mathrm{pH}$ values in stool samples in comparison with healthy and UC groups. Additionally, the LA-GOS treatment caused a reduction in the $\mathrm{pH}$ level from UC animals in comparison with untreated UC mice. Data are expressed as the mean \pm SD and statistically analyzed via one way ANOVA test followed by Dunnett's multiple comparison test. $\left({ }^{* *} p \leq 0.005\right.$ and $\left.{ }^{* * *} p \leq 0.001\right)$.

\section{Discussion}

Lupinus albus is an important legume in animal and human nutrition due to the high content of protein and other compounds, including fiber and a high proportion of GOS $[39,70]$. Studies have demonstrated the prebiotic potential of GOS with increases of Bifidobacterium and Lactobacillus in in vivo and in vitro models [40,48,71]. In addition, the prebiotic effect is not only in the site of utilization, GOS have been studied for their prebiotics benefits in the lungs and brain [72].

In recent years, prebiotics have taken great relevance in the complementary treatment of several diseases, such as obesity, colon cancer, and inflammatory bowel disease [73-75]. However, the effect of GOS from Lupinus albus (LA-GOS) has not been investigated in ulcerative colitis. Since ulcerative colitis is a frequent disease in the modern lifestyle, the use of vegetal compounds like LA-GOS could be an alternative to complement the management in a natural way.

The results of this study showed that LA-GOS treatment significantly reduced certain histopathological characteristics developed by the ulcerative colitis as disease activity index, the cellular infiltration in the mucosa, and submucosa and intestinal inflammation. The intestinal epithelium possesses a mucus layer that avoids the pathogen translocation and is important to maintain the colonic epithelium health. Goblet cells are the main cellular source of mucus production. Therefore, a higher number of goblet cells is desirable to ameliorate the severity of ulcerative colitis [76]. LA-GOS administration maintains the length of colon and the integrity of the crypt, reducing the extensive ulcerations and increasing the number of goblet cells.

These results can be compared with those founded by Dai and colleagues in 2017, where Raffinose Oligosaccharides (RFOs) from soybean were extracted, enzymatically modified, and used in a DSS-induced colitis model [77]. Interestingly, our data show a 
better improvement in the reduction of the histopathological grade of severity in ulcerative colitis in comparison to soybean RFOs.

On the other hand, a pharmacological grade compound that contains oligosaccharides $\left(\mathrm{GFO}^{\circledR}\right)$ (Otsuka Pharmaceutical Co., Ltd., Tokyo, Japan) was tested in an in vivo ulcerative colitis [67] and a decreased DAI, maintained length of colon, and a higher number of goblet cells were observed as in our study. However, the same results were reached with a dose 10-times lower in our case. In addition, the authors did not perform a semiquantitative analysis of the number of goblet cells. These data support that LA-GOS can be a suitable treatment in comparison with another type of oligosaccharides.

Colonic tissue is structured by a double mucus layer and a simple epithelium [78]. Intestinal epithelial cells (IECs) constitute a continuous physical barrier. Adjacent IECs are connected by tight junctions (TJ) that are associated with the transport of substances and the epithelium permeability [79]. There are three main TJ protein families: claudin, occluding, and junctional adhesion molecules. Claudins are the major determinants of TJ barrier proteins. Some members of the claudin family act by plugging the paracellular pathway, while others function as paracellular channels [80]. Specifically, claudin 1 acts predominantly as a barrier claudin [81].

Claudin 1 is located in the junctional areas as well as in the lateral membranes of crypt epithelial cells [33]. Downregulation of claudin- 1 contributes to increased intestinal permeability through NF-kB pathway activation [82]. In ulcerative colitis in vivo models, it has been observed that the claudin-1 protein is significantly decreased in colonic tissue $[54,83]$. In agreement with these previous reports, we found a reduced claudin- 1 expression in the UC model.

On the other hand, we observed an improved claudin 1 expression in the UC model after LA-GOS treatment in comparison with the untreated UC group. These results are concordant with the SCFA production by the gut microbiota, particularly with the amount of butyrate and its regulatory effect on the TJ $[31,84,85]$. On the other hand, other TJ proteins that are disrupted in ulcerative colitis must be considered to improve our work.

In health conditions, the gut microbiota is a complex microorganism community with several beneficial properties to the host [86]. The intestinal microbiota participates in the protection against external pathogens, in the digestion and absorption of nutrients, regulates metabolism, modulates the immune system, among other functions [87]. Recently, several studies have proven that the imbalance of intestinal microbiota is associated with multiple diseases [88-90].

Ulcerative colitis (UC) is a disease characterized by the proportion shift of intestinal microbiota. In comparison with healthy individuals, UC patients were observed to have a reduced microbial diversity, especially in specific phylum, like Firmicutes. On the contrary, an increase of the phyla Bacteroidetes and Proteobacteria are presented in UC [74]. Many reports have demonstrated the beneficial use of natural compounds as new therapeutic candidates of UC. In fact, oligosaccharides have been evaluated in this disease due to their prebiotic role [91,92].

In our study, we found that LA-GOS treatment in comparison with the UC untreated group increased the Bacteroidetes phylum. On the other hand, the Proteobacteria phylum was reduced in both healthy + LA-GOS and UC + LA-GOS groups. In addition, the Firmicutes phylum increases in both groups treated with LA-GOS (healthy and UC groups). This augment in the Bacteroidetes phylum after treatment correlates with the results of Xu and cols. [54] and Guo and colleagues [89]. The change of the abundance in Bacteroidetes phylum could be clinically meaningful since it has been associated with IBD in comparison with healthy individuals [89].

Although a reduction of the Firmicutes phylum was shown subsequent to the treatment in those studies, in our work, this phylum was increased through LA-GOS administration. The abundance of Firmicutes phylum is associated with specific butyrate producer bacteria, such as Faecalibacterium prausnitzii, Roseburia sp., and Eubacterium rectale. LA-GOS treatment improve the butyrate producer bacteria (Figure S2). 
The Proteobacteria phylum is reduced after LA-GOS treatment, similar results were found by Guo, indicating that the low abundance of this phylum could improve dysbiosis in UC [89]. In addition, the association of an inflammatory environment is highlighted with an up-regulated proportion of Proteobacteria in UC [93]. Notwithstanding the used methodology, the reduction of total bacteria in an experimental UC model is consistent with the results found in other studies $\mathrm{Xu}$ and cols. [54] and Guo and colleagues [89]. Remarkably, we observed that LA-GOS treatment increased the total bacteria in comparison with the UC untreated group that is commonly associated with intestinal health [94].

The production of SCFAs has been related with prebiotics and gut microbiota. Among the SCFAs produced by the intestinal microbiota, butyrate exerts multiple health benefits to the host [95]. A wide range of human butyrate-producing strains belonging mainly to the Firmicutes phylum. In fact, butyrate is produced by two pathways: butyrate kinase/phosphotransbutyrylase (Buk) pathway and butyryl coenzyme A (CoA): acetate CoA transferase (But) pathway [62]. Here, we decided to quantify the But gene since it is related to the main pathway used by the microbiota [96].

It has been observed that the But gene is significantly decreased in fecal microbiota from patients with UC [97]. The reduction of the abundance of the But gene after experimental UC is in agreement with this finding. However, LA-GOS administration does not increase the But gene abundance after the period of treatment. In another study, it was reported that oligosaccharides administration (FOS), did not modify the But gene abundance in spite of a longer treatment period (9 weeks) [51].

Notably, we found a significant augment in the But gene abundance of the healthy + LA-GOS group in comparison with the untreated healthy group. An explanation for these results could be the impaired association between the abundance of total bacteria and the But gene positive bacteria. The total bacteria were reduced in both UC groups and, in the healthy groups, were maintained. Thus, in a healthy environment, LA-GOS administration promotes the abundance of But gene positive bacteria, while in experimental UC, it is not able to preserve this abundance in the total microbial community.

The breakdown of resistant starch and undigested carbohydrates by the gut microbiota promotes the production of SCFAs [69]. The most abundant SCFAs are acetic, propionic, and butyric acids. These three acids represent around $90-95 \%$ of the SCFA total production in the human colon [7]. These acids are involved in many physiological functions as source of energy, gene expression regulators, ligands to specific receptors in enterocytes and immune cells, participation in tight junction mechanisms, modulation of lipids and carbohydrates metabolism, and $\mathrm{pH}$ regulation in the intestine and feces [98,99].

The total SCFA production has been evaluated in patients with IBD, these patients show reduced levels of SCFAs in intestinal mucosa and feces [100]. The main modification of SCFAs profile in patients with UC reduction of butyric acid levels. On the other hand, many reports showed that acetic and propionic acids levels were normal or reduced in UC patients [101]. In agreement, we found that the total SCFAs and the acetic acid concentrations remained without modifications in all treated and untreated groups. The total SCFA production can be compared with the results of Ferrer and cols. in 2020 [102].

These authors did not find any significant differences between control group and Crohn Disease (CD) patients. The intestinal homeostasis is associated with the amount of SCFAs. Nevertheless, the diminution of total bacteria is associated with the down levels of SCFAs [31]. We can speculate that the total SCFAs concentration maintenance particularly in the UC group could be explained by the damage of the intestine and the down regulation in the SCFAs transport to enterocytes [103].

The acetic acid is principally produced by Bacteroidetes phylum and Bifidobacterium genus. The acetic acid is the major SCFAs produced and is converted into acetyl-CoA. Later, acetyl-CoA can be metabolized into the tricarboxylic acid cycle to generate energy [74]. In addition, the acetate is used by specific species of the Firmicutes phylum (Faecalibacterium prausnitzii and Roseburia sp.) to produce butyric acid through the butyrylCoA: acetate CoA transferase pathway [68]. The 50\% of butyrate producers used acetate to 
produce butyrate [104]. This knowledge supports the increase of the Bacteroidetes phylum as well as the acetic acid level maintenance in the UC + LA-GOS group.

The propionic acid is produced by some species of Bacteroidetes phylum, Firmicutes phylum, Bifidobacterium generous and salmonella spp. [98]. The propionic acid level was significantly reduced by the LA-GOS treatment in the UC model in comparison with healthy and UC groups. In a healthy environment, propionate participates in the regulation of gluconeogenesis and cholesterol synthesis in the liver. The effect of propionate is controversial since it has been related with intestinal anti-inflammatory effects and prevention of pathogen colonization [29].

On the other hand, in patients with $C D$, this promotes a virulent form of the adherentinvasive Escherichia coli [105]. The modulation of propionate could be associated with other molecules, like the amino acids and $\mathrm{pH}$ level. A linear correlation has been described in relation to the propionate and $\mathrm{pH}$ levels [106]. Taken together, we can hypothesize that propionic acid concentration in the UC + LA-GOS treatment could be conceivably related with the low abundance of proteobacteria phylum or with the $\mathrm{pH}$ decrease.

Butyric acid is the most dynamic of the three mentioned SCFAs. It is the source of $70 \%$ of the energy for the intestinal epithelial cells, increases the MUC2 gene expression and mucin production, decreases cell proliferation, and enhances the epithelial barrier [107]. It is produced by the Firmicutes Phylum specifically by the following four families: Ruminococcaceae, Lachnospiraceae, Erysipelotrichaceae, and Clostridiaceae [98]. The main species related to the production of butyrate are F. prausnitzii, Eubacterium rectale, Eubacterium Hallii, and Roseburia intestinali $[98,108]$. In our study, the butyric acid concentration increases after LA-GOS treatment in healthy mice. Butyric acid levels could be explained by the increase in Firmicutes phylum and the But gene positive bacteria after LA-GOS treatment in healthy conditions.

Potentially, colonic acidity environment provides protection against colonization of pathogen bacteria (Salmonella typhimurium, Escherichia coli, and Shigella sp.) [109]. Moreover, $\mathrm{pH}$ levels are inversely associated with SCFAs concentration [30]. Accordingly, in an in vitro study, acetic acid inhibited the growth of many common pathogens, especially at a lower $\mathrm{pH}$ [110]. In our results, we found that LA-GOS treatment significantly reduced the colonic $\mathrm{pH}$ under healthy and UC conditions. In a previous study of our group, we demonstrated that the $\mathrm{pH}$ level is a regulator of immune cell activity, including neutrophils.

In general, neutrophils are implicated in the inflammatory process related with intestinal damage in the UC model [111]. A lower $\mathrm{pH}$ reduced the production of Neutrophil Extracellular Traps (NET) by neutrophils [112]. The decrease of NET could be associated with an improvement in the intestinal health and anti-inflammatory effects. These facts could support the observed health beneficial effect of $\mathrm{pH}$ level reduction after LA-GOS treatment (Figure S3). Our study sets the basis for future research focused on identifying bacteria families, genus and species involved in the SCFA production and the potential role of LA-GOS treatment in this intestinal ecosystem.

\section{Conclusions}

In this work, we demonstrated, for the first time, the effect of LA-GOS treatment in the reduction of DAI and inflammatory process in UC. In addition, a stratification of DAI and inflammatory process versus the number of $B u t$ gene positive bacteria will be important to justify the use of prebiotics. Moreover, it is necessary to realize more studies to augment the number of studied animals, modulate the dosage of DSS, and include inflammatory biomarkers, such as cytokines and immune cells. The use of glucocorticoid must consider control of the inflammatory response. 
Supplementary Materials: The following are available online at https:/ / www.mdpi.com/article /10.3390/biom11111658/s1, Figure S1. Differents dosages of LA-GOS increase the Butyryl-CoA transferase gene positive bacteria, Figure S2. LA-GOS treatment improves the relative abundance of butyrate producer bacteria, Figure S3. Potential mechanism of LA-GOS treatment in ulcerative colitis model.

Author Contributions: Conceptualization, L.A.G.-M., V.D.-R. and C.M.G.-D.; methodology, J.S.Z.-N., N.V.-M., R.I.L.-R. and P.M.G.-L.; software: R.I.L.-R. and J.S.Z.-N.; histophatology analysis, J.S.Z.N. and L.A.G.-M.; investigation, L.A.G.-M., L.I.-G., M.F.-M. and V.D.-R.; writing-original draft preparation, L.A.G.-M.; writing-review and editing and supervision, V.D.-R. and C.M.G.-D.; proyect administration, V.D.-R.; funding acquisition, V.D.-R. and M.F.-M. All authors have read and agreed to the published version of the manuscript.

Funding: The author(s) disclosed receipt of the following financial support for the research, authorship, and/or publication of this article: This work was supported by the Universidad de Guadalajara through "PROSNI 2018-2021", "Programa de fortalecimiento de la investigación y el prosgrado (2020)" and "Programa de fortalecimiento de institutos, Centro y Laboratorios de investigación (2021)" and "PIN-2020-I".

Institutional Review Board Statement: The study was conducted according to the laboratory animals established in the Mexican Official Standard (NOM-062-ZOO-1999) and approved by the ethics, Investigaction and Biosafety committees from the University Center of Health Sciences (CUCS), University of Guadalajara, with a registration number CI-0042.

Informed Consent Statement: Not applicable.

Data Availability Statement: Not applicable.

Acknowledgments: We would like to acknowledge to the Royal Society of Chemistry Journal for approve contained in the Table 1 in our article. In addition, we acknowledge to the E Century Publishing for the Table 2.

Conflicts of Interest: The authors declare no conflict of interest.

\section{References}

1. Feng, Q.; Chen, W.D.; Wang, Y.D. Gut Microbiota: An Integral Moderator in Health and Disease. Front. Microbiol. 2018, 9, 151. [CrossRef]

2. Sender, R.; Fuchs, S.; Milo, R. Revised Estimates for the Number of Human and Bacteria Cells in the Body. PLoS Biol. 2016, 14, e1002533. [CrossRef] [PubMed]

3. Arumugam, M.; Raes, J.; Pelletier, E.; Le Paslier, D.; Yamada, T.; Mende, D.R.; Fernandes, G.R.; Tap, J.; Bruls, T.; Batto, J.-M. Enterotypes of the human gut microbiome. Nature 2011, 473, 174-180. [CrossRef]

4. Belizário, J.E.; Napolitano, M. Human microbiomes and their roles in dysbiosis, common diseases, and novel therapeutic approaches. Front. Microbiol. 2015, 6, 1050. [CrossRef] [PubMed]

5. Angelakis, E.; Lagier, J.-C. Samples and techniques highlighting the links between obesity and microbiota. Microb. Pathog. 2017, 106, 119-126. [CrossRef]

6. $\quad$ Bäckhed, F.; Fraser, C.M.; Ringel, Y.; Sanders, M.E.; Sartor, R.B.; Sherman, P.M.; Versalovic, J.; Young, V.; Finlay, B.B. Defining a healthy human gut microbiome: Current concepts, future directions, and clinical applications. Cell Host Microbe 2012, 12, 611-622. [CrossRef]

7. Ríos-Covián, D.; Ruas-Madiedo, P.; Margolles, A.; Gueimonde, M.; De Los Reyes-Gavilán, C.G.; Salazar, N. Intestinal short chain fatty acids and their link with diet and human health. Front. Microbiol. 2016, 7, 185. [CrossRef]

8. Qiu, F.; Zhang, Z.; Yang, L.; Li, R.; Ma, Y. Combined effect of vitamin C and vitamin D 3 on intestinal epithelial barrier by regulating Notch signaling pathway. Nutr. Metab. 2021, 18, 49. [CrossRef] [PubMed]

9. Flint, H.J.; Scott, K.P.; Louis, P.; Duncan, S.H. The role of the gut microbiota in nutrition and health. Nat. Rev. Gastroenterol. Hepatol. 2012, 9, 577-589. [CrossRef]

10. Dethlefsen, L.; McFall-Ngai, M.; Relman, D.A. An ecological and evolutionary perspective on human-microbe mutualism and disease. Nature 2007, 449, 811-818. [CrossRef]

11. Singh, R.K.; Chang, H.-W.; Yan, D.; Lee, K.M.; Ucmak, D.; Wong, K.; Abrouk, M.; Farahnik, B.; Nakamura, M.; Zhu, T.H. Influence of diet on the gut microbiome and implications for human health. J. Transl. Med. 2017, 15, 73. [CrossRef]

12. Wilkins, L.J.; Monga, M.; Miller, A.W. Defining dysbiosis for a cluster of chronic diseases. Sci. Rep. 2019, 9, 12918. [CrossRef] [PubMed]

13. DeGruttola, A.K.; Low, D.; Mizoguchi, A.; Mizoguchi, E. Current understanding of dysbiosis in disease in human and animal models. Inflamm. Bowel Dis. 2016, 22, 1137-1150. [CrossRef] 
14. Pérez-Reytor, D.; Puebla, C.; Karahanian, E.; García, K. Use of short-chain fatty acids for the recovery of the intestinal epithelial barrier affected by bacterial toxins. Front. Physiol. 2021, 12, 721. [CrossRef] [PubMed]

15. Colombel, J.; Ungaro, R.; Mehandru, S.; Allen, P.B.; Peyrin-Biroulet, L.; Colombel, J.-F. Ulcerative colitis. Lancet 2017, 389, 1756-1770.

16. Zakerska-Banaszak, O.; Tomczak, H.; Gabryel, M.; Baturo, A.; Wolko, L.; Michalak, M.; Malinska, N.; Mankowska-Wierzbicka, D.; Eder, P.; Dobrowolska, A. Dysbiosis of gut microbiota in Polish patients with ulcerative colitis: A pilot study. Sci. Rep. 2021, 11, 2166. [CrossRef]

17. Shen, Z.-H.; Zhu, C.-X.; Quan, Y.-S.; Yang, Z.-Y.; Wu, S.; Luo, W.-W.; Tan, B.; Wang, X.-Y. Relationship between intestinal microbiota and ulcerative colitis: Mechanisms and clinical application of probiotics and fecal microbiota transplantation. World $J$. Gastroenterol. 2018, 24, 5. [CrossRef]

18. Taku, K.; Britta, S.; Chen, W.S.; Ferrante, M.; Shen, B.; Bernstein, C.N.; Silvio, D.; Laurent, P.-B.; Toshifumi, H. Ulcerative colitis (Primer). Nat. Rev. Dis. Primers 2020, 6, 1-20. [CrossRef]

19. Low, D.; Nguyen, D.D.; Mizoguchi, E. Animal models of ulcerative colitis and their application in drug research. Drug Des. Dev. Ther. 2013, 7, 1341.

20. Laroui, H.; Ingersoll, S.A.; Liu, H.C.; Baker, M.T.; Ayyadurai, S.; Charania, M.A.; Laroui, F.; Yan, Y.; Sitaraman, S.V.; Merlin, D. Dextran sodium sulfate (DSS) induces colitis in mice by forming nano-lipocomplexes with medium-chain-length fatty acids in the colon. PLoS ONE 2012, 7, e32084. [CrossRef]

21. Rubin, D.T.; Ananthakrishnan, A.N.; Siegel, C.A.; Sauer, B.G.; Long, M.D. ACG clinical guideline: Ulcerative colitis in adults. Off. J. Am. Coll. Gastroenterol. 2019, 114, 384-413. [CrossRef] [PubMed]

22. Buchman, A.L. Side effects of corticosteroid therapy. J. Clin. Gastroenterol. 2001, 33, 289-294. [CrossRef] [PubMed]

23. Morelli, L.; Capurso, L. FAO/WHO guidelines on probiotics: 10 years later. J. Clin. Gastroenterol. 2012, 46, S1-S2. [CrossRef] [PubMed]

24. Gibson, G.R.; Hutkins, R.; Sanders, M.E.; Prescott, S.L.; Reimer, R.A.; Salminen, S.J.; Scott, K.; Stanton, C.; Swanson, K.S.; Cani, P.D. Expert consensus document: The International Scientific Association for Probiotics and Prebiotics (ISAPP) consensus statement on the definition and scope of prebiotics. Nat. Rev. Gastroenterol. Hepatol. 2017, 14, 491-502. [CrossRef] [PubMed]

25. Bubnov, R.; Babenko, L.; Lazarenko, L.; Kryvtsova, M.; Shcherbakov, O.; Zholobak, N.; Golubnitschaja, O.; Spivak, M. Can tailored nanoceria act as a prebiotic? Report on improved lipid profile and gut microbiota in obese mice. EPMA J. 2019, 10, 317-335. [CrossRef]

26. Delgado, G.T.C.; Tamashiro, W.M.d.S.C. Role of prebiotics in regulation of microbiota and prevention of obesity. Food Res. Int. 2018, 113, 183-188. [CrossRef]

27. Sivieri, K.; Morales, M.L.V.; Saad, S.M.; Adorno, M.A.T.; Sakamoto, I.K.; Rossi, E.A. Prebiotic effect of fructooligosaccharide in the simulator of the human intestinal microbial ecosystem (SHIME ${ }^{\circledR}$ model). J. Med. Food 2014, 17, 894-901. [CrossRef]

28. Kushkevych, I.; Kotrsová, V.; Dordević, D.; Buňková, L.; Vítězová, M.; Amedei, A. Hydrogen sulfide effects on the survival of lactobacilli with emphasis on the development of inflammatory bowel diseases. Biomolecules 2019, 9, 752. [CrossRef]

29. Markowiak-Kopeć, P.; Śliżewska, K. The effect of probiotics on the production of short-chain fatty acids by human intestinal microbiome. Nutrients 2020, 12, 1107. [CrossRef]

30. Den Besten, G.; Van Eunen, K.; Groen, A.K.; Venema, K.; Reijngoud, D.-J.; Bakker, B.M. The role of short-chain fatty acids in the interplay between diet, gut microbiota, and host energy metabolism. J. Lipid Res. 2013, 54, 2325-2340. [CrossRef]

31. Parada Venegas, D.; De la Fuente, M.K.; Landskron, G.; González, M.J.; Quera, R.; Dijkstra, G.; Harmsen, H.J.; Faber, K.N.; Hermoso, M.A. Short chain fatty acids (SCFAs)-mediated gut epithelial and immune regulation and its relevance for inflammatory bowel diseases. Front. Immunol. 2019, 10, 277. [CrossRef]

32. Ahmad, M.; Krishnan, S.; Ramakrishna, B.; Mathan, M.; Pulimood, A.; Murthy, S. Butyrate and glucose metabolism by colonocytes in experimental colitis in mice. Gut 2000, 46, 493-499. [CrossRef]

33. Zhu, L.; Han, J.; Li, L.; Wang, Y.; Li, Y.; Zhang, S. Claudin family participates in the pathogenesis of inflammatory bowel diseases and colitis-associated colorectal cancer. Front. Immunol. 2019, 10, 1441. [CrossRef]

34. Deleu, S.; Machiels, K.; Raes, J.; Verbeke, K.; Vermeire, S. Short chain fatty acids and its producing organisms: An overlooked therapy for IBD? EBioMedicine 2021, 66, 103293. [CrossRef]

35. Vargas-Guerrero, B.; García-López, P.M.; Martínez-Ayala, A.L.; Domínguez-Rosales, J.A.; Gurrola-Díaz, C.M. Administration of Lupinus albus gamma conglutin $(\mathrm{C} \gamma)$ to 5 STZ rats augmented Ins-1 gene expression and pancreatic insulin content. Plant Foods Human Nutr. 2014, 69, 241-247. [CrossRef] [PubMed]

36. Arnoldi, A.; Greco, S. Nutritional and nutraceutical characteristics of lupin protein. Nutrafoods 2011, 10, 23-29. [CrossRef]

37. Lee, Y.P.; Mori, T.A.; Puddey, I.B.; Sipsas, S.; Ackland, T.R.; Beilin, L.J.; Hodgson, J.M. Effects of lupin kernel flour-enriched bread on blood pressure: A controlled intervention study. Am. J. Clin. Nutr. 2009, 89, 766-772. [CrossRef] [PubMed]

38. Guzmán, T.J.; Martínez-Ayala, A.L.; García-López, P.M.; Soto-Luna, I.C.; Gurrola-Díaz, C.M. Effect of the acute and chronic administration of Lupinus albus $\beta$-conglutin on glycaemia, circulating cholesterol, and genes potentially involved. Biomed. Pharmacother. 2021, 133, 110969. [CrossRef] [PubMed]

39. Martinez-Villaluenga, C.; Frías, J.; Vidal-Valverde, C.; Gomez, R. Raffinose family of oligosaccharides from lupin seeds as prebiotics: Application in dairy products. J. Food Prot. 2005, 68, 1246-1252. [CrossRef] 
40. Villaluenga, C.M.; Wardeńska, M.; Pilarski, R.; Bednarczyk, M.; Gulewicz, K. Utilization of the chicken embryo model for assessment of biological activity of different oligosaccharides. Folia Biol. 2004, 52, 135-142. [CrossRef]

41. Stadnicka, K.; Bogucka, J.; Stanek, M.; Graczyk, R.; Krajewski, K.; Maiorano, G.; Bednarczyk, M. Injection of raffinose family oligosaccharides at 12 days of egg incubation modulates the gut development and resistance to opportunistic pathogens in broiler chickens. Animals 2020, 10, 592. [CrossRef]

42. Gullón, P.; Gullón, B.; Tavaria, F.; Vasconcelos, M.; Gomes, A.M. In vitro fermentation of lupin seeds (Lupinus albus) and broad beans (Vicia faba): Dynamic modulation of the intestinal microbiota and metabolomic output. Food Funct. 2015, 6, 3316-3322. [CrossRef] [PubMed]

43. Xiang, S.; Ye, K.; Li, M.; Ying, J.; Wang, H.; Han, J.; Shi, L.; Xiao, J.; Shen, Y.; Feng, X. Xylitol enhances synthesis of propionate in the colon via cross-feeding of gut microbiota. Microbiome 2021, 9, 62. [CrossRef] [PubMed]

44. Bach Knudsen, K.E. Microbial degradation of whole-grain complex carbohydrates and impact on short-chain fatty acids and health. Adv. Nutr. 2015, 6, 206-213. [CrossRef] [PubMed]

45. Uerlings, J.; Bindelle, J.; Schroyen, M.; Richel, A.; Bruggeman, G.; Willems, E.; Everaert, N. Fermentation capacities of fructan-and pectin-rich by-products and purified fractions via an in vitro piglet faecal model. J. Sci. Food Agric. 2019, 99, 5720-5733. [CrossRef] [PubMed]

46. Gulewicz, P.; Ciesiołka, D.; Frias, J.; Vidal-Valverde, C.; Frejnagel, S.; Trojanowska, K.; Gulewicz, K. Simple method of isolation and purification of $\alpha$-galactosides from legumes. J. Agric. Food Chem. 2000, 48, 3120-3123. [CrossRef] [PubMed]

47. Shakappa, D.; Talari, A.; Rajkumar, H.; Shujauddin, M. Hypolipidemic effect of red gram (Cajanus cajan L.) prebiotic oligosaccharides in Wistar NIN Rats. J. Diet. Suppl. 2018, 15, 410-418. [CrossRef]

48. Li, T.; Lu, X.; Yang, X. Stachyose-enriched $\alpha$-galacto-oligosaccharides regulate gut microbiota and relieve constipation in mice. J. Agric. Food Chem. 2013, 61, 11825-11831. [CrossRef] [PubMed]

49. Li, T.; Lu, X.; Yang, X. Evaluation of clinical safety and beneficial effects of stachyose-enriched $\alpha$-galacto-oligosaccharides on gut microbiota and bowel function in humans. Food Funct. 2017, 8, 262-269. [CrossRef] [PubMed]

50. Chappuis, E.; Morel-Depeisse, F.; Bariohay, B.; Roux, J. Alpha-galacto-oligosaccharides at low dose improve liver steatosis in a high-fat diet mouse model. Molecules 2017, 22, 1725. [CrossRef]

51. Valcheva, R.; Koleva, P.; Martínez, I.; Walter, J.; Gänzle, M.G.; Dieleman, L.A. Inulin-type fructans improve active ulcerative colitis associated with microbiota changes and increased short-chain fatty acids levels. Gut Microbes 2019, 10, 334-357. [CrossRef]

52. Djouzi, Z.; ANDIUEUX, C. Compared effects of three oligosaccharides on metabolism of intestinal microflora in rats inoculated with a human faecal flora. Br. J. Nutr. 1997, 78, 313-324. [CrossRef]

53. Chassaing, B.; Aitken, J.D.; Malleshappa, M.; Vijay-Kumar, M. Dextran sulfate sodium (DSS)—Induced colitis in mice. Curr. Protoc. Immunol. 2014, 104, 15-25. [CrossRef] [PubMed]

54. Xu, Z.; Chen, W.; Deng, Q.; Huang, Q.; Wang, X.; Yang, C.; Huang, F. Flaxseed oligosaccharides alleviate DSS-induced colitis through modulation of gut microbiota and repair of the intestinal barrier in mice. Food Funct. 2020, 11, 8077-8088. [CrossRef] [PubMed]

55. Erben, U.; Loddenkemper, C.; Doerfel, K.; Spieckermann, S.; Haller, D.; Heimesaat, M.M.; Zeitz, M.; Siegmund, B.; Kühl, A.A. A guide to histomorphological evaluation of intestinal inflammation in mouse models. Int. J. Clin. Exp. Pathol. 2014, 7, 4557. [PubMed]

56. Zhao, F.; Zhou, G.; Liu, X.; Song, S.; Xu, X.; Hooiveld, G.; Müller, M.; Liu, L.; Kristiansen, K.; Li, C. Dietary protein sources differentially affect the growth of Akkermansia muciniphila and maintenance of the gut mucus barrier in mice. Mol. Nutr. Food Res. 2019, 63, 1900589. [CrossRef] [PubMed]

57. Święch, E.; Tuśnio, A.; Barszcz, M.; Taciak, M.; Siwiak, E. Goblet cells and mucus layer in the gut of young pigs: Response to dietary contents of threonine and non-essential amino acids. J. Anim. Physiol. Anim. Nutr. 2019, 103, 894-905. [CrossRef]

58. Thomas, V.; Clark, J.; Doré, J. Fecal microbiota analysis: An overview of sample collection methods and sequencing strategies. Future Microbiol. 2015, 10, 1485-1504. [CrossRef]

59. Hutter, G.; Schlagenhauf, U.; Valenza, G.; Horn, M.; Burgemeister, S.; Claus, H.; Vogel, U. Molecular analysis of bacteria in periodontitis: Evaluation of clone libraries, novel phylotypes and putative pathogens. Microbiology 2003, 149, 67-75. [CrossRef] [PubMed]

60. Vigsnæs, L.K.; Holck, J.; Meyer, A.S.; Licht, T.R. In vitro fermentation of sugar beet arabino-oligosaccharides by fecal microbiota obtained from patients with ulcerative colitis to selectively stimulate the growth of Bifidobacterium spp. and Lactobacillus spp. Appl. Environ. Microbiol. 2011, 77, 8336-8344. [CrossRef]

61. Wang, W.; Xing, W.; Wei, S.; Gao, Q.; Wei, X.; Shi, L.; Kong, Y.; Su, Z. Semi-rational screening of probiotics from the fecal flora of healthy adults against DSS-induced colitis mice by enhancing anti-inflammatory activity and modulating the gut microbiota. $J$. Microbiol. Biotechnol. 2019, 29, 1478. [CrossRef] [PubMed]

62. Louis, P.; Flint, H.J. Development of a semiquantitative degenerate real-time pcr-based assay for estimation of numbers of butyryl-coenzyme A (CoA) CoA transferase genes in complex bacterial samples. Appl. Environ. Microbiol. 2007, 73, $2009-2012$. [CrossRef]

63. Livak, K.J.; Schmittgen, T.D. Analysis of relative gene expression data using real-time quantitative PCR and the $2^{-\Delta \Delta C T}$ method. Methods 2001, 25, 402-408. [CrossRef] [PubMed] 
64. Ribeiro, W.R.; Vinolo, M.A.R.; Calixto, L.A.; Ferreira, C.M. Use of gas chromatography to quantify short chain fatty acids in the serum, colonic luminal content and feces of mice. Bio-Protocol 2018, 8, e3089. [CrossRef] [PubMed]

65. Shimizu, K.; Seiki, I.; Goto, Y.; Murata, T. Measurement of the Intestinal pH in Mice under Various Conditions Reveals Alkalization Induced by Antibiotics. Antibiotics 2021, 10, 180. [CrossRef]

66. Kind, S.; Büscheck, F.; Höflmayer, D.; Hube-Magg, C.; Kluth, M.; Tsourlakis, M.C.; Steurer, S.; Clauditz, T.S.; Luebke, A.M.; Burandt, E. Claudin-1 upregulation is associated with favorable tumor features and a reduced risk for biochemical recurrence in ERG-positive prostate cancer. World J. Urol. 2020, 38, 2185-2196. [CrossRef]

67. Joo, E.; Yamane, S.; Hamasaki, A.; Harada, N.; Matsunaga, T.; Muraoka, A.; Suzuki, K.; Nasteska, D.; Fukushima, T.; Hayashi, T. Enteral supplement enriched with glutamine, fiber, and oligosaccharide attenuates experimental colitis in mice. Nutrition 2013, 29, 549-555. [CrossRef]

68. Duncan, S.H.; Barcenilla, A.; Stewart, C.S.; Pryde, S.E.; Flint, H.J. Acetate utilization and butyryl coenzyme A (CoA): Acetate-CoA transferase in butyrate-producing bacteria from the human large intestine. Appl. Environ. Microbiol. 2002, 68, 5186-5190. [CrossRef]

69. Morrison, D.J.; Preston, T. Formation of short chain fatty acids by the gut microbiota and their impact on human metabolism. Gut Microbes 2016, 7, 189-200. [CrossRef]

70. Kouris-Blazos, A.; Belski, R. Health benefits of legumes and pulses with a focus on Australian sweet lupins. Asia Pac. J. Clin. Nutr. 2016, 25, 1-17.

71. Logtenberg, M.J.; Akkerman, R.; Hobe, R.; Donners, K.M.; Van Leeuwen, S.S.; Hermes, G.D.; de Haan, B.J.; Faas, M.M.; Buwalda, P.L.; Zoetendal, E.G. Structure-Specific Fermentation of Galacto-Oligosaccharides, Isomalto-Oligosaccharides and Isomalto/Malto-Polysaccharides by Infant Fecal Microbiota and Impact on Dendritic Cell Cytokine Responses. Mol. Nutr. Food Res. 2021, 2001077. [CrossRef]

72. Reid, G.; Abrahamsson, T.; Bailey, M.; Bindels, L.B.; Bubnov, R.; Ganguli, K.; Martoni, C.; O’Neill, C.; Savignac, H.M.; Stanton, C. How do probiotics and prebiotics function at distant sites? Benef. Microbes 2017, 8, 521-533. [CrossRef]

73. Qamar, T.R.; Syed, F.; Nasir, M.; Rehman, H.; Zahid, M.N.; Liu, R.H.; Iqbal, S. Novel combination of prebiotics galactooligosaccharides and inulin-inhibited aberrant crypt foci formation and biomarkers of colon cancer in wistar rats. Nutrients 2016, 8, 465. [CrossRef] [PubMed]

74. He, L.; Zhang, F.; Jian, Z.; Sun, J.; Chen, J.; Liapao, V.; He, Q. Stachyose modulates gut microbiota and alleviates dextran sulfate sodium-induced acute colitis in mice. Saudi J. Gastroenterol. Off. J. Saudi Gastroenterol. Assoc. 2020, 26, 153. [CrossRef] [PubMed]

75. Everard, A.; Belzer, C.; Geurts, L.; Ouwerkerk, J.P.; Druart, C.; Bindels, L.B.; Guiot, Y.; Derrien, M.; Muccioli, G.G.; Delzenne, N.M. Cross-talk between Akkermansia muciniphila and intestinal epithelium controls diet-induced obesity. Proc. Natl. Acad. Sci. USA 2013, 110, 9066-9071. [CrossRef] [PubMed]

76. Gersemann, M.; Becker, S.; Kübler, I.; Koslowski, M.; Wang, G.; Herrlinger, K.R.; Griger, J.; Fritz, P.; Fellermann, K.; Schwab, M. Differences in goblet cell differentiation between Crohn's disease and ulcerative colitis. Differentiation 2009, 77, 84-94. [CrossRef]

77. Dai, Z.; Feng, S.; Liu, A.; Wang, H.; Zeng, X.; Yang, C.S. Anti-inflammatory effects of newly synthesized $\alpha$-galacto-oligosaccharides on dextran sulfate sodium-induced colitis in C57BL/6J mice. Food Res. Int. 2018, 109, 350-357. [CrossRef] [PubMed]

78. Johansson, M.E.; Larsson, J.M.H.; Hansson, G.C. The two mucus layers of colon are organized by the MUC2 mucin, whereas the outer layer is a legislator of host-microbial interactions. Proc. Natl. Acad. Sci. USA 2011, 108, 4659-4665. [CrossRef] [PubMed]

79. Peterson, L.W.; Artis, D. Intestinal epithelial cells: Regulators of barrier function and immune homeostasis. Nat. Rev. Immunol. 2014, 14, 141-153. [CrossRef]

80. Lu, Z.; Ding, L.; Lu, Q.; Chen, Y.-H. Claudins in intestines: Distribution and functional significance in health and diseases. Tissue Barriers 2013, 1, e24978. [CrossRef]

81. Günzel, D.; Yu, A.S. Claudins and the modulation of tight junction permeability. Physiol. Rev. 2013, 93, 525-569. [CrossRef]

82. Zhou, Q.; Costinean, S.; Croce, C.M.; Brasier, A.R.; Merwat, S.; Larson, S.A.; Basra, S.; Verne, G.N. MicroRNA 29 targets nuclear factor- $\mathrm{kB}-$ repressing factor and Claudin 1 to increase intestinal permeability. Gastroenterology 2015, 148, 158-169. [CrossRef]

83. Mennigen, R.; Nolte, K.; Rijcken, E.; Utech, M.; Loeffler, B.; Senninger, N.; Bruewer, M. Probiotic mixture VSL\# 3 protects the epithelial barrier by maintaining tight junction protein expression and preventing apoptosis in a murine model of colitis. Am. J. Physiol.-Gastrointest. Liver Physiol. 2009, 296, G1140-G1149. [CrossRef] [PubMed]

84. Chen, G.; Ran, X.; Li, B.; Li, Y.; He, D.; Huang, B.; Fu, S.; Liu, J.; Wang, W. Sodium butyrate inhibits inflammation and maintains epithelium barrier integrity in a TNBS-induced inflammatory bowel disease mice model. EBioMedicine 2018, 30, 317-325. [CrossRef] [PubMed]

85. Wang, H.-B.; Wang, P.-Y.; Wang, X.; Wan, Y.-L.; Liu, Y.-C. Butyrate enhances intestinal epithelial barrier function via up-regulation of tight junction protein Claudin-1 transcription. Dig. Dis. Sci. 2012, 57, 3126-3135. [CrossRef] [PubMed]

86. Dieterich, W.; Schink, M.; Zopf, Y. Microbiota in the gastrointestinal tract. Med. Sci. 2018, 6, 116. [CrossRef] [PubMed]

87. Nishida, A.; Inoue, R.; Inatomi, O.; Bamba, S.; Naito, Y.; Andoh, A. Gut microbiota in the pathogenesis of inflammatory bowel disease. Clin. J. Gastroenterol. 2018, 11, 1-10. [CrossRef] [PubMed]

88. Hirayama, M.; Ohno, K. Parkinson's Disease and Gut Microbiota. Ann. Nutr. Metab. 2021, 77, 28-35. [CrossRef] [PubMed]

89. Guo, S.; Geng, W.; Chen, S.; Wang, L.; Rong, X.; Wang, S.; Wang, T.; Xiong, L.; Huang, J.; Pang, X. Ginger alleviates DSS-induced ulcerative colitis severity by improving the diversity and function of gut microbiota. Front. Pharmacol. 2021, 12, 53. 
90. Patel, B.K.; Patel, K.H.; Bhatia, M.; Iyer, S.G.; Madhavan, K.; Moochhala, S.M. Gut microbiome in acute pancreatitis: A review based on current literature. World J. Gastroenterol. 2021, 27, 5019. [CrossRef]

91. Gopalakrishnan, A.; Clinthorne, J.F.; Rondini, E.A.; McCaskey, S.J.; Gurzell, E.A.; Langohr, I.M.; Gardner, E.M.; Fenton, J.I. Supplementation with galacto-oligosaccharides increases the percentage of NK cells and reduces colitis severity in Smad3-deficient mice. J. Nutr. 2012, 142, 1336-1342. [CrossRef] [PubMed]

92. Grabinger, T.; Glaus Garzon, J.F.; Hausmann, M.; Geirnaert, A.; Lacroix, C.; Hennet, T. Alleviation of intestinal inflammation by oral supplementation with 2-fucosyllactose in mice. Front. Microbiol. 2019, 10, 1385. [CrossRef] [PubMed]

93. Vester-Andersen, M.; Mirsepasi-Lauridsen, H.; Prosberg, M.; Mortensen, C.; Träger, C.; Skovsen, K.; Thorkilgaard, T.; Nøjgaard, C.; Vind, I.; Krogfelt, K.A. Increased abundance of proteobacteria in aggressive Crohn's disease seven years after diagnosis. Sci. Rep. 2019, 9, 13473. [CrossRef]

94. Tsuji, H.; Matsuda, K.; Nomoto, K. Counting the countless: Bacterial quantification by targeting rRNA molecules to explore the human gut microbiota in health and disease. Front. Microbiol. 2018, 9, 1417. [CrossRef]

95. Brame, J.E.; Liddicoat, C.; Abbott, C.A.; Breed, M.F. The potential of outdoor environments to supply beneficial butyrate-producing bacteria to humans. Sci. Total Environ. 2021, 777, 146063. [CrossRef] [PubMed]

96. Jian, C.; Luukkonen, P.; Yki-Järvinen, H.; Salonen, A.; Korpela, K. Quantitative PCR provides a simple and accessible method for quantitative microbiota profiling. PLoS ONE 2020, 15, e0227285. [CrossRef]

97. Shinohara, R.; Sasaki, K.; Inoue, J.; Hoshi, N.; Fukuda, I.; Sasaki, D.; Kondo, A.; Osawa, R. Butyryl-CoA: Acetate CoA-transferase gene associated with the genus Roseburia is decreased in the gut microbiota of Japanese patients with ulcerative colitis. Biosci. Microbiota Food Health 2019, 38, 18-29. [CrossRef]

98. Louis, P.; Flint, H.J. Formation of propionate and butyrate by the human colonic microbiota. Environ. Microbiol. 2017, 19, 29-41. [CrossRef]

99. Sivaprakasam, S.; Prasad, P.D.; Singh, N. Benefits of short-chain fatty acids and their receptors in inflammation and carcinogenesis. Pharmacol. Ther. 2016, 164, 144-151. [CrossRef] [PubMed]

100. Huda-Faujan, N.; Abdulamir, A.; Fatimah, A.; Anas, O.M.; Shuhaimi, M.; Yazid, A.; Loong, Y. The impact of the level of the intestinal short chain fatty acids in inflammatory bowel disease patients versus healthy subjects. Open Biochem. J. $2010,4,53$. [CrossRef]

101. Russo, E.; Giudici, F.; Fiorindi, C.; Ficari, F.; Scaringi, S.; Amedei, A. Immunomodulating activity and therapeutic effects of short chain fatty acids and tryptophan post-biotics in inflammatory bowel disease. Front. Immunol. 2019, 10, 2754. [CrossRef] [PubMed]

102. Ferrer-Picón, E.; Dotti, I.; Corraliza, A.M.; Mayorgas, A.; Esteller, M.; Perales, J.C.; Ricart, E.; Masamunt, M.C.; Carrasco, A.; Tristán, E. Intestinal inflammation modulates the epithelial response to butyrate in patients with inflammatory bowel disease. Inflamm. Bowel Dis. 2020, 26, 43-55. [CrossRef]

103. Sivaprakasam, S.; Bhutia, Y.D.; Ramachandran, S.; Ganapathy, V. Cell-surface and nuclear receptors in the colon as targets for bacterial metabolites and its relevance to colon health. Nutrients 2017, 9, 856. [CrossRef]

104. Barcenilla, A.; Pryde, S.E.; Martin, J.C.; Duncan, S.H.; Stewart, C.S.; Henderson, C.; Flint, H.J. Phylogenetic relationships of butyrate-producing bacteria from the human gut. Appl. Environ. Microbiol. 2000, 66, 1654-1661. [CrossRef] [PubMed]

105. Ormsby, M.J.; Johnson, S.A.; Carpena, N.; Meikle, L.M.; Goldstone, R.J.; McIntosh, A.; Wessel, H.M.; Hulme, H.E.; McConnachie, C.C.; Connolly, J.P. Propionic acid promotes the virulent phenotype of Crohn's disease-associated adherent-invasive Escherichia coli. Cell Rep. 2020, 30, 2297-2305.e5. [CrossRef] [PubMed]

106. Walker, A.W.; Duncan, S.H.; McWilliam Leitch, E.C.; Child, M.W.; Flint, H.J. pH and peptide supply can radically alter bacterial populations and short-chain fatty acid ratios within microbial communities from the human colon. Appl. Environ. Microbiol. 2005, 71,3692-3700. [CrossRef]

107. Plöger, S.; Stumpff, F.; Penner, G.B.; Schulzke, J.D.; Gäbel, G.; Martens, H.; Shen, Z.; Günzel, D.; Aschenbach, J.R. Microbial butyrate and its role for barrier function in the gastrointestinal tract. Ann. N. Y. Acad. Sci. 2012, 1258, 52-59. [CrossRef]

108. Rivière, A.; Selak, M.; Lantin, D.; Leroy, F.; De Vuyst, L. Bifidobacteria and butyrate-producing colon bacteria: Importance and strategies for their stimulation in the human gut. Front. Microbiol. 2016, 7, 979. [CrossRef]

109. Sun, Y.; O'Riordan, M.X. Regulation of bacterial pathogenesis by intestinal short-chain fatty acids. Adv. Appl. Microbiol. 2013, 85, 93-118.

110. Van Limpt, C.; Crienen, A.; Vriesema, A.; Knol, J. 134 Effect of Colonic Short Chain Fatty Acids, Lactate and PH on The Growth of Common Gut Pathogens. Pediatric Res. 2004, 56, 487. [CrossRef]

111. Muthas, D.; Reznichenko, A.; Balendran, C.A.; Böttcher, G.; Clausen, I.G.; Kärrman Mårdh, C.; Ottosson, T.; Uddin, M.; MacDonald, T.T.; Danese, S. Neutrophils in ulcerative colitis: A review of selected biomarkers and their potential therapeutic implications. Scand. J. Gastroenterol. 2017, 52, 125-135. [CrossRef] [PubMed]

112. Íñiguez-Gutiérrez, L.; Godínez-Méndez, L.A.; Fafutis-Morris, M.; Padilla-Arellano, J.R.; Corona-Rivera, A.; Bueno-Topete, M.R.; Rojas-Rejón, Ó.A.; Delgado-Rizo, V. Physiological concentrations of short-chain fatty acids induce the formation of neutrophil extracellular traps in vitro. Int. J. Immunopathol. Pharmacol. 2020, 34, 2058738420958949. [CrossRef] [PubMed] 